\title{
INNOVATIVE THERAPIES FOR HEMOGLOBIN DISORDERS
}

Karine Sii-Felice ${ }^{1^{*}}$, Olivier Negre ${ }^{1,2,3^{*}}$, Christian Brendel $^{2}$, Alisa Tubsuwan ${ }^{4}$, Eglantine Morel-à-l'Huissier ${ }^{1}$, Camille Filardo ${ }^{1}$, Emmanuel Payen ${ }^{1}$

\section{ABSTRACT}

$\beta$-globin gene transfer has been used as a paradigm for hematopoietic stem cell (HSC) gene therapy, but is subject to major difficulties, such as the lack of selection of genetically corrected HSCs, the need for high-level expression of the therapeutic gene, and cell-specific transgene expression. It took more than 40 years for scientists and physicians to advance from the cloning of globin gene and discovering globin gene mutations to improving our understanding of the pathophysiological mechanisms involved, the detection of genetic modifiers, the development of animal models and gene transfer vectors, comprehensive animal testing, and demonstrations of phenotypic improvement in clinical trials, culminating in the authorization of the first gene therapy product for $\beta$-thalassemia in 2019. Research has focused mostly on the development of lentiviral gene therapy vectors expressing variants of the $\beta$-globin gene, or more recently targeting a $\gamma$-globin repressor, some of which have entered clinical testing and should soon diversify the available treatments and promote price competition. These results are encouraging, but we have yet to reach the end of the story. New molecular and cellular tools, such as gene editing or the development of induced pluripotent stem cells, are being developed, heralding the emergence of alternative products, the efficacy and safety of which are being studied. Hemoglobin disorders constitute an important model for testing the pros and cons of these advanced technologies, some of which are already in the clinical phase. In this review, we focus on the development of the advanced products, and recent technological innovations which could lead to clinical trials in the near future, and provide hope for a definitive cure of these severe conditions.

"These authors contributed equally

\section{Corresponding author}

Emmanuel Payen - emmanuel.payen@cea.fr

${ }^{1}$ Division of Innovative Therapies and UMR 1184 IMVA-HB, Institute of Biology François Jacob, CEA, INSERM, Paris-Saclay University, Fontenay aux Roses, France.

2 Dana-Farber/Boston Children's Cancer and Blood Disorders Center, Harvard Medical School, Boston MA, USA

${ }^{3}$ Biotherapy Partners SAS, Paris, France

4 Institute of Molecular Biosciences, Mahidol University, Nakhon Pathom, Thailand

\section{KEY POINTS}

- Advances in the development of lentiviral gene therapies in hematopoietic stem cells have led to clinical benefits in several patients with $\beta$-thalassemia and sickle cell disease.

- Gene editing approaches for hemoglobinopathies are exciting and have already started to transition from lab to clinic.

\section{INTRODUCTION}

\subsection{Hemoglobin disorders}

$\beta$-hemoglobin disorders are the most common singlegene disorders worldwide. They affect hundreds of thousands of newborns each year [1], not only in regions of endemic malaria [2] but throughout the world $[3,4]$ due to population movements [5].

In patients with $\beta$-thalassemia, an imbalance between the $\alpha$ - and $\beta$-globin chains causes the precipitation of unstable $\alpha$-globin/heme complexes in erythroid precursors, ineffective erythropoiesis and 
hemolytic anemia [6], resulting in erythroid hyperplasia and the dysregulation of iron homeostasis, which worsens the impairment of erythropoiesis [7]. A distinction is made between subjects producing small amounts of the $\beta$-globin chain (non- $\beta^{0} / \beta^{0}$ or $\beta^{+}$-thalassemia) and patients entirely lacking this chain ( $\beta^{0} / \beta^{0}$-thalassemia), but the various forms of $\beta$-thalassemia are best graded on the basis of $\mathrm{Hb}$ levels, clinical tolerance and transfusion dependence. The most severe form of $\beta$-thalassemia, transfusion-dependent thalassemia (TDT), requires lifelong red blood cell transfusions, resulting in iron overload and complications, such as heart failure, liver fibrosis and endocrine disease [8]. The leading cause of early death in these patients is cardiac disease [9, 10], but increases in lifespan will probably reveal the effects of risk factors on other causes of premature morbidity and mortality, such as infection [11], liver disease [12], hepatocarcinoma [13] and various other complications [14].

Sickle cell disease $(S C D)$ results from the substitution of a valine for a glutamic acid in the $\beta$ globin chain of sickle hemoglobin tetramers (HbS, $\alpha_{2} \beta_{2}^{S}$ ). This amino acid interacts with a hydrophobic pocket on the surface of another tetramer, initiating the aggregation of deoxy-HbS into long fibers that modify the structure and rheological properties of red blood cells [15]. HbS polymerization and erythrocyte injury cause vaso-occlusive disease, hemolytic anemia, endothelial dysfunction and chronic inflammation [16, 17]. All these processes are mutually self-sustaining and act in synergy to cause acute pain and end-organ failure. Sickle cell syndromes include sickle cell anemia (SCA), the genotype of which is homozygosity for $\beta^{\text {S }}$ (p.Glu6Val in $H B B$ ), and other forms resulting from the coinheritance of one $\beta^{\mathrm{S}}$ allele and another $H B B$ variant. These include sickle $\beta^{0}$-thalassemia ( $\mathrm{HbS} \beta^{0}$-thal), sickle $\beta^{+}$-thalassemia ( $\mathrm{HbS} \beta^{+}$-thal) and sickle-hemoglobin $\mathrm{C}$ disease ( $\mathrm{HbSC})$. The clinical features of $\mathrm{HbS} \beta^{+}-$thal and $\mathrm{HbSC}$ are generally less severe than those in SCA [18]. $\mathrm{HbS} \beta^{\circ}$-thal is generally considered clinically indistinguishable from SCA, although some studies have reported a slightly lower incidence of SCD comorbidities [19].

Until recently, allogeneic hematopoietic stem cell transplantation (HSCT) was the only consolidated curative approach for severe $\beta$-hemoglobinopathies. In a recent international study including 1000 SCD patients receiving matched sibling donor cells, fiveyear overall survival was $92.9 \%$ and event-free survival was $91.4 \%$ [20]. Over the last 30 years, HSCT has been used to treat $\beta$-thalassemia patients with severe forms of the disease, mostly through the infusion of HLAmatched sibling donor cells in pediatric recipients, resulting in an event-free survival of more than $80 \%$ and an overall survival of $90 \%$ [21]. For both disorders, the long-term quality of life is better in patients successfully treated by curative HSCT than in patients treated by noncurative symptomatic therapy $[22,23]$. High-resolution HLA-typing has made it possible to achieve satisfactory outcomes in a limited number of TDT patients receiving cells from matched unrelated donors [24], but the risk of graft-versus-host disease is much higher than that in the matched sibling donor setting and is considered unacceptable in SCD [25]. Thus, despite the advantages of its curative nature, HSCT entails greater short-term risks than conservative therapy. For patients without a sibling donor and those at high risk of transplantation-related morbidity, gene therapy is a promising alternative medical approach.

\subsection{Goal of gene therapies}

Improvement of the $\beta$-thalassemia phenotype requires the expression of sufficient amounts of $\beta$ likeglobin chain to restore the $\alpha / \beta$-globin chain balance. This can be achieved with the $\beta$-globin gene itself, which can be transferred or corrected, the $\gamma$-globin gene, which can be transferred or induced, or any engineered variant producing a protein capable of associating with $\alpha$-globin chains through a mechanism similar to that operating in adult $\left(\mathrm{HbA}, \alpha_{2} \beta_{2}\right)$ of fetal ( $\left.\mathrm{HbF}, \alpha_{2} \gamma_{2}\right)$ hemoglobin. In SCD, the objective is to express a $\beta$ like-globin gene sufficiently strongly to dilute the $\beta^{\text {s}}$-globin chain effectively and to disrupt the $\mathrm{HbS}$ polymerization process. $\mathrm{HbF}$ impairs $\mathrm{HbS}$ polymerization, and its concentration in erythrocytes is correlated with an improvement of clinical symptoms [26]. Red blood cells containing HbS together with $\mathrm{HbF}$ sickle less readily than cells with a similar proportion of $\mathrm{HbA}$ [27]. Thus, the transfer of the fetal $\gamma$-globin gene into HSCs or the reactivation of its expression in adult erythroid cells is a valuable therapeutic approach for this disease. $\mathrm{HbF}$ and the minor component of adult erythrocytes $\operatorname{HbA2}\left(\alpha_{2} \delta_{2}\right)$ have similar sparing effects on intracellular $\mathrm{HbS}$ polymerization [28]. The hydrophobic interaction between $\beta^{\mathrm{S}}$ and $\gamma / \delta$-globin chains is destabilized by the glutamine residue at position $87\left(\mathrm{G} \mid n-\gamma / \delta^{87}\right)$ [29-31], which is a threonine residue in $\beta$-globin chains. A mutated $\beta^{\text {T870 }}$-globin variant has been shown to inhibit $\mathrm{HbS}$ polymerization as efficiently as the $\gamma$-globin chain 
in vitro [32]. The $\beta^{\text {T87Q }}$-globin gene can thus be expressed via gene therapy vectors, both to compensate for the $\beta$-globin chain deficiency in $\beta$ thalassemia and to destabilize the $\mathrm{HbS}$ polymer in SCD. It has two key advantages over the $\gamma$ - and $\delta$-globin genes: i) $\gamma$-globin mRNAs are not very stable in cells containing significant numbers of $\beta$-globin transcripts $[33,34]$ and ii) the affinity of the beta subunit for the $\alpha$-globin chain is greater than that of the $\gamma$ - or $\delta$-chains $[35,36]$. These properties make the formation of the $\mathrm{HbA}$ tetramer, and most likely of $\mathrm{HbA}^{\mathrm{T} 87 \mathrm{Q}}\left(\alpha_{2} \beta^{\mathrm{A}-\mathrm{T} 87 \mathrm{Q}_{2}}\right)$, more likely than that of $\mathrm{HbF}$ or $\mathrm{HbA} 2$ at similar levels of gene transcription and/or vector copy numbers. Another potentially interesting intermolecular contact within the polymer is the axial interaction between the Glu- $\beta^{22}$ and His- $\alpha^{20}$ residues of adjacent tetramers. The replacement of Glu- $\beta^{22}$ with an alanine residue has been shown to interfere with $\mathrm{HbS}$ polymerization in vitro [30] and the incorporation of this substitution into anti-sickling $\beta$-globin variants to produce $\beta^{\mathrm{AS} 2}\left(\beta^{\mathrm{A}-}\right.$ T870/E22A) has been proposed [37]. However, the E22A mutation decreases the negative charge on the $\beta$ subunit, which may decrease its ability to dimerize with $\alpha$-globin chains [38]. A third mutation $\left(\beta^{16}\right.$ Gly $\rightarrow$ Asp), known as HbJ-Baltimore, was added to compensate for the loss of the negatively charged amino acid [39]. Single- and triple-mutated $\beta$-globin variants ( $\beta^{\text {T87Q }}$ and $\beta^{\mathrm{AS} 3}$ ) have anti-sickling effects similar to that of $\mathrm{HbF}$ in vitro $[32,39]$. Their relative effectiveness has yet to be determined.

The most advanced gene therapy technology is based on the ex vivo modification of HSCs and infusion of the genetically modified cells after myeloablative conditioning. These therapeutic methods, at various stages of development into clinical applications, are based on the addition of genes via lentiviral vectors, the use of guided nucleases to modify genome elements, or gene repair through homologous recombination. Other technologies are being studied in animal models, including the use of genetically modified induced pluripotent stem cells (IPSCS), the nucleotide modification of specific target sites, and the genetic modification of cells in vivo.

\section{PRECLINICAL STUDIES}

\subsection{Globin gene addition}

Gene therapy requires the development of tools i) mediating a long-lasting effect through gene integration into the HSC genome, ii) transferring a sequence long enough, including large distal enhancer element, for expression of the globin gene to sustained and therapeutic levels in erythroid cells, and iii) minimizing the risk of insertional oncogenesis. The combination of core elements of the $\beta$-globin locus control region (LCR) made it possible to generate sequences capable of promoting high levels of gene expression in erythroid cells [40, 41], but their introduction into gamma-retroviral vectors ( $\gamma$-RVVs) resulted in low vector titers [42, 43], limited expression[43], position effect variegation [44], and poor transduction of the mouse HSCs used for transplantation [45]. Removal of the DNA structures responsible for the low titers increased vector stability $[46,47]$, but long-term expression levels in erythroid cells after transplantation remained low [44, 48]. It was ultimately the advent of lentiviral vectors (LVVs) that made it possible to consider treating hemoglobinopathies by ex-vivo gene transfer into HSCs. Side-by-side comparisons of LVVs containing either the minimal LCR sequence, such as those that could be introduced into $\gamma$-RVVs $(\approx 1 \mathrm{~kb})$, and longer genomic fractions of the $\beta$-globin locus control region (LCR) confirmed the superiority of LVVs for exporting complex sequences and expressing the $\beta$-globin gene in mice [49]. Another advantage of LVVs is their ability to transduce nondividing cells [50], which is of paramount importance because HSCs are mostly quiescent [51].

The first studies demonstrating the value of LVVs for the treatment of hemoglobin disorders by the autologous transplantation of genetically modified HSCs were published in the early 2000s by the groups of Leboulch and Sadelain [32, 49, 52, 53]. The HPV403, HPV436 and TNS9 vectors were essentially similar (Figure 1 ). The $\beta$-globin gene was introduced in its entirety, with the exception of a deletion of an AT-rich region in intron 2 , potentially responsible for vector instability $[46,47]$. The DNase I-hypersensitive sites 2 , 3 and 4 , corresponding to about $3 \mathrm{~kb}$ of the $\beta$-globin LCR (Figure 1), were included to ensure high expression levels. One of the differences between these vectors lay in the therapeutic genes, $\beta^{\mathrm{A}}$-globin in TNS9 and HPV403, and $\beta^{\text {A-T87Q }}$-globin in HPV436, which had a glutamine residue in place of the threonine in position $\beta^{87}$ [32]. The central polypurine tract/central termination sequence (cPPT/CTS) of HIV-1 was incorporated into the HPV403 and HPV436 constructs to increase viral titers and HSC transduction [32]. 


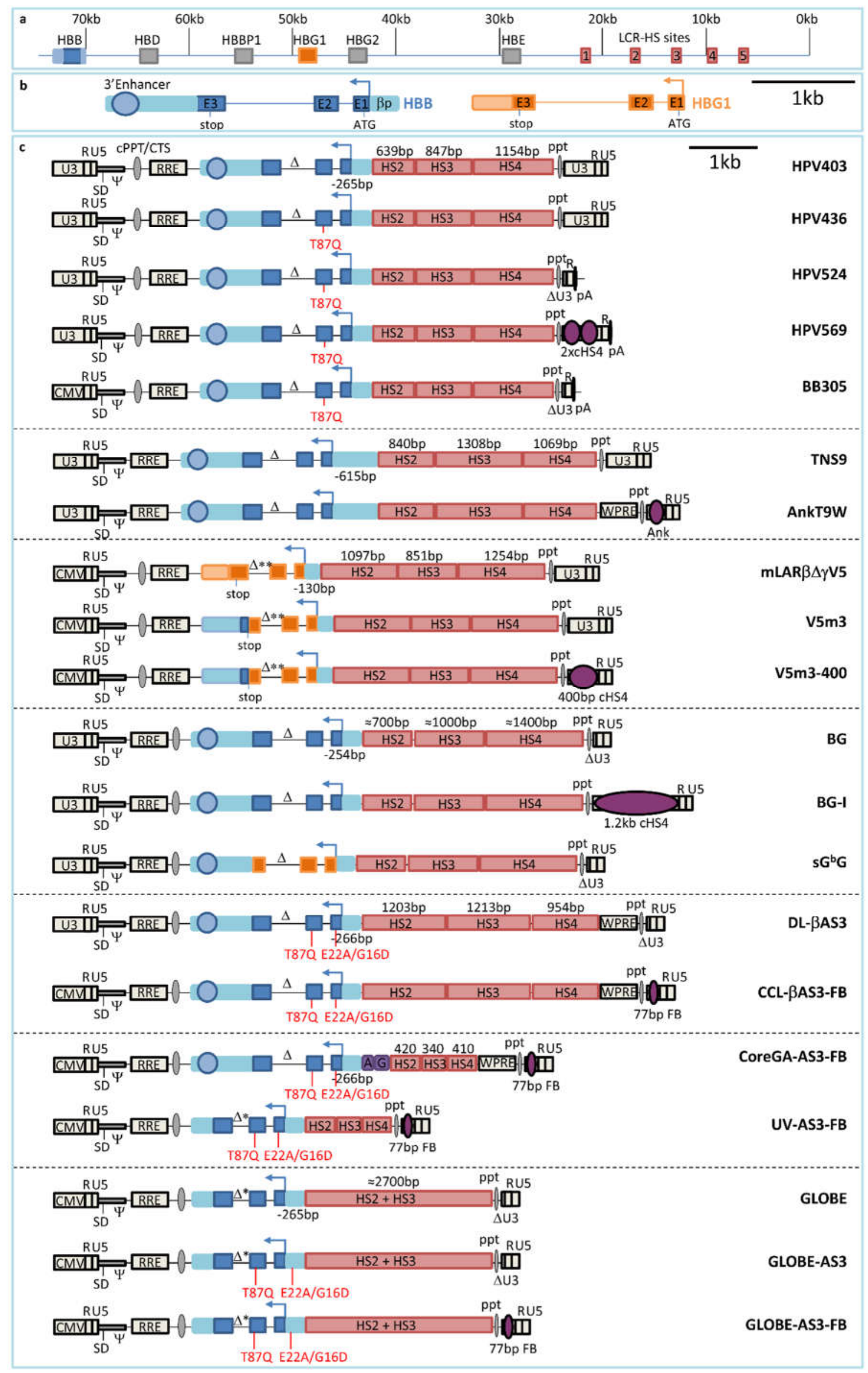


Figure 1: Lentiviral vector expressing $\beta$-globin variants. a The beta globin locus (NG_000007.3), including DNAse-1 hypersensitive sites $1,2,3,4$ and 5 (HS1, HS2, HS3, HS4, HS5), embryonic (HBE), fetal (HBG1 and HBG2), and adult (HBD and $H B B)$ globin genes, and a pseudogene (HBBP1). b The $H B G 1$ and $H B B$ genes including exons (E1, E2, E3), introns, untranslated regions, and regulatory sequences used to construct the lentiviral vectors shown in C. c Structure of the lentiviral vectors, in their plasmid form, described in this review. Each group, separated by a dotted line, consists of a prototype (top) and its derivatives. The sizes of the LCR HS and of the promoter, indicated for the prototypes, are the same in the derived vectors. Amino-acid modifications (relative to the open reading phase in the $H B B$ gene) are indicated in red, and the insulating elements are indicated by purple ellipses. U3, R, U5: HIV long terminal repeat (LTR), CMV, R, U3: CMV/HIV-hybrid 5' LTR, $\triangle U 3$ : 3' self-inactivating LTR. cPPT/CTS: central polypurine track/central termination sequence, $\Psi$ : packaging sequence, RRE: Rev-responsive element, WPRE: Woodchuck hepatitis virus post-transcriptional regulatory element, $\triangle$ and $\Delta^{*}$ : 374 and 593 bp deletions, respectively, within HBB intron 2, $\Delta^{* *}$ : 720 bp deletion within HBG1 intron 2, FB: minimal CTCF-binding site (FII) of the $250 \mathrm{bp}$ core of the $1.2 \mathrm{~kb}$ chicken $\beta$-globin HS4 and the analogous region of the human T-cell receptor $\delta / \alpha$ BEAD-1 insulator, $\mathrm{G}$ and A: Regulatory elements from the erythroid cell-specific murine GATA1 and human Ank1 genes, respectively. HPV403 [52], HPV436 [32], HPV524 [241], HPV569 [98], BB305 [74], TNS9 [49], AnkT9W [100], mLAR $3 \Delta \gamma V 5$ [57], V5m3 [62], V5m3-400 [116], BG [58], BG-I [68], SGb [104], DL-ßaS3 [64], CCL-ßaS3-FB [93], CoreGA-AS3-FB [99], UV-AS3-FB [99], GLOBE [59], GLOBE-AS3 [108], GLOBE-AS3-FB [94].

\subsection{1 $\beta$-thalassemia}

Mice reproducing the cellular defects observed in humans with $\beta$-thalassemia intermedia (classified as non-transfusion-dependent thalassemia, NTDT) [54, $55]$, were used to study the efficacy of human $\beta$ globin-expressing vectors to correct the disease. Longterm high-level human $\beta$-chain expression was achieved with the LVVs TNS9 and HPV403 [49, 52, 53]. The level of expression was high enough to reduce the free $\alpha$-chain imbalance, to restore hemoglobin levels, to improve red blood cell morphology, to correct dyserythropoiesis, to prevent extramedullary hematopoiesis, and to correct iron overload. Incorporation of the cPPT/CTS element [56] into the HPV403 vector may have made it possible to obtain a higher titer and to transduce the cells more efficiently. Indeed, the mean vector copy number (VCN) per leukocyte was $\approx 3$ rather than $\approx 1$ (copies per diploid genome) in peripheral leukocytes, and the human $\beta$ globin chain accounted for a mean of $32.4 \%$ of all $\beta$ globin chains with HPV403, rather than the $21.0 \%$ observed with TNS9. A number of similar LVVs have since been developed (Figure 1), all capable of producing high levels of $\beta$-like globin chains in mouse models of $\beta$-thalassemia and/or in primary human cells [57-59]. Overall, the preclinical studies demonstrated that LVVs can be used to transfer complex DNA sequences, including the $\beta$-globin LCR, to achieve expression levels much higher than those achieved with $\gamma$-RVVs, and they demonstrated the feasibility of complete correction for $\beta$-thalassemia.

\subsubsection{Sickle cell disease}

The $\beta^{\mathrm{T} 87 \mathrm{Q}_{-}}$globin chain is as potent as the $\gamma$-globin chain for inhibiting $\mathrm{HbS}$ polymerization in vitro, and the oxygen affinity of $\mathrm{HBA}^{\mathrm{T} 8 \mathrm{Q}}$ is within the range observed for $\mathrm{HbA}$ [32]. The first LVV tested in mouse models of sickle cell disease thus encoded the $\beta^{\text {T87Q }}$-globin protein (HPV436, Figure 1). High titers and a high VCN (mean value of $\approx 3$ ) per leukocyte were obtained upon HSC transduction and transplantation, resulting in pancellular erythroid expression. Two models were used: the SAD [60] and Berkeley (BERK) [61] mouse models. The BERK mice closely model $\mathrm{HbS} \beta^{0}$-thal patients, a population of severely affected individuals also likely to benefit from gene therapy. An inhibition of sickling at low oxygen pressure and the disappearance of irreversibly sickled cells was observed in mice receiving marrow cells transduced with the HPV436 vector [32]. In red blood cells harvested from the recipient mice, $\mathrm{HbS}$ polymerization was delayed in vitro and similar to that measured in cells from asymptomatic AS heterozygous human subjects. In BERK mice receiving $\gamma$-globin LVVtransduced cells, $30 \%$ to $50 \% \mathrm{HbF}$ was sufficient to protect mice against organ damage [62]. The use of a vector encoding the triple anti-sickling variant $\beta^{\mathrm{AS3}}$ in a mouse model resembling BERK mice [63] led to the correction of red blood cell morphology, a decrease in the frequency of vaso-occlusive events, and an improvement in splenic, liver and kidney diseases in mice with $\approx 25 \% \mathrm{Hb}^{\mathrm{AS} 3}$. This percentage is similar to that of $\mathrm{HbF}$ in SCD patients with hereditary persistence of fetal hemoglobin (HPFH) and mild disease [64]. As the anti-polymerization activities of the $\beta^{\mathrm{AS3}}$ and $\beta^{\mathrm{A}-}$

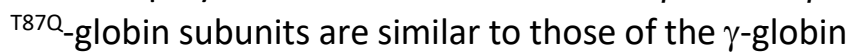
chain, these results suggest that $25 \% \mathrm{Hb}^{\mathrm{AS3}}$ or $\mathrm{HbA}^{\mathrm{T} 87 \mathrm{Q}}$ would be sufficient for the successful treatment of SCD patients with gene therapy, provided that expression is evenly distributed among a majority of erythrocytes [65].

\subsubsection{Chromosomal position effect}

These pioneering studies also showed that the elements used to control $\beta$-globin gene expression in LVVs were sensitive to silencing [32, 49, 52]. An 
analysis of individual clones obtained upon the transduction of erythroid cells revealed considerable variation in the levels of $\beta$-globin gene expression. A high gene transfer efficacy and the integration of multiple copies resulted in the pancellular erythroid expression of the human gene, whereas, in mice with a mean VCN of one per cell, heterocellular expression persisted [32, 52, 66]. Position-dependent expression was also observed in erythroid mouse cells transduced with $\mathrm{mLAR} \beta \Delta \gamma \mathrm{V} 5$ and $\mathrm{V} 5 \mathrm{~m} 3$, two $\gamma$-globin LVVs containing $3.2 \mathrm{~kb}$ of LCR elements [57, 62]. Thus, despite the promising results obtained with LVVs containing extensive LCR sequences, the position effect remained an issue, and the mean lentiviral VCN required for consistent correction in human red blood cells remained unclear at this stage of preclinical studies. As a means of protecting the $\beta / \gamma$-globin LVVs against the encroachment of adjacent inactive chromatin, insulators with heterochromatin barrier activity were introduced into their 3'LTR [67]. Insertion of the $1.2 \mathrm{~kb}$ chromatin insulator of the chicken $\beta$-globin $5^{\prime}$ DNAse I-hypersensitive site 4 (cHS4), into the BG LVV 3'LTR (BG-I) doubled the probability of $\beta$-globin gene expression in erythroid cell lines and mouse red blood cells [68]. However, it also resulted in a 10-fold decrease in vector titer [69]. Two copies of the cHS4 250 bp core element were also inserted into the BG and HPV569 LVVs, but characterization of these vectors showed that the tandem repeats recombined at a high frequency [69, 70], resulting in the loss of one of the two cores. Unfortunately, one copy was reported to have only mild barrier activity in several studies [71-73]. Flanking with a 650 bp fragment combining the 5' 250 bp core and the 3' 400 bp sequences of the $1.2 \mathrm{~kb} \mathrm{cHS} 4$ insulator resulted in the maintenance of barrier activity in RBCs of thalassemic mice [72], with only a two- to three-fold loss of viral titer [69, 72]. This may, nevertheless, pose a significant problem as regards the therapeutic potential of the vector, as decreases in titer are known to be accompanied by an additional decrease in the infectivity of hematopoietic cells [36, $73,74]$. Thus, the small effect of barrier insulators on the probability of cells expressing the transgene at a constant level is counterbalanced by the costs, in terms of titer and transduction efficiency $[75,76]$.

\subsubsection{Insertional mutagenesis}

LVVs carrying active long terminal repeat (LTR) enhancer sequences efficiently activate oncogenes in vivo $[77,78]$ and disturb cellular gene regulation within a large window around the insertion site [79], suggesting that they are not inherently safer than $\gamma$ RVVs. Nevertheless, in side-by-side comparisons, the genotoxic potential of LVVs is lower than that of $\gamma$ RVVs $[77,80]$, due to the preferential targeting of promoter regions by $\gamma$-RVVs and of intragenic regions by LVVs [81]. Self-inactivating (SIN) vectors are safer [77], especially when gene promoters with low enhancer promiscuity are used to control transgene expression [82]. Due to their restricted expression, tissue-specific promoters can decrease the risk of oncogene activation in non-target cells [83]. Thus, in the LVVs currently being developed for gene therapy, strong LTR enhancers are deleted, and internal cellular gene promoters are preferred over strong ubiquitous transcriptional elements for the control of therapeutic gene expression [84]. The $\beta$-globin LCR is a long-range enhancer that can generate high levels of erythroidspecific expression for cis-linked genes [85], affects chromatin structure over a distance of 200 kilobases [86], and has an active chromatin configuration before commitment to the erythroid lineage $[87,88]$. The $\approx 3$ $\mathrm{kb}$ LCR enhancer elements present in the globin LVVs $\mathrm{mLAR} \beta \Delta \gamma \mathrm{V} 5$ and $B G$ have been shown to dysregulate cellular genes within at least 600 kilobases around the site of insertion in primary erythroid cells [89], and have a residual capacity to immortalize primary murine hematopoietic cells in vitro [80]. As a means of shielding the genome from the internal enhancer, and further minimizing genotoxic impact, the addition of insulator elements, such as the cHS4 insulator element, has been proposed [90, 91]. Following its introduction into the 3'LTR of BG LVV, the $1.2 \mathrm{~kb}$ element, or its $650 \mathrm{bp}$ derivative, has been shown to decrease genotoxicity slightly in vitro [80]. The FII/BEAD-1 (FB) composite 77 bp fragment has been shown to decrease the genotoxic potential of strong viral enhancer elements [92], with a minimal effect on $\beta$-globin LVV titers $[93,94]$. FB is, thus, a potentially interesting insulator, although its blocking activity in the globin LVVs into which it has been inserted has not been formally evaluated.

The enhancer-blocking activity of insulators has been shown to be context-dependent [95], variable according to the promoters activated [96], and only partially effective in vitro and in vivo [73]. LVV-mediated genotoxicity may also occur through mechanisms other than simple enhancer/promoter interaction, and may interfere with the splicing of primary transcripts [97]' [98]. For these reasons, and those discussed above, few of the viral vectors 
developed to date contain these elements. It was decided to remove the insulator sequence from the HPV569 LVV [74], after this vector had been used clinically [98], but to keep retain it in Lenti/ $\beta A S 3-F B$ LVVs $[93,99]$.

\subsubsection{Comparison of globin LVVs}

A strict inter-vector comparison between studies, based on preclinical data and the proportion of transgenic hemoglobin normalized according to VCN, would not be appropriate, for several reasons: i) the correlation between transgenic hemoglobin levels and VCN is not linear; ii) red blood cells with the highest levels of therapeutic globin expression appear in the bloodstream due to in vivo selection; iii) in vivo selection depends on the levels of dyserythropoiesis and/or red blood cell survival; iv) the competition between endogenous and exogenous $\beta$-like globin genes and proteins, in terms of expression, translation, dimerization with $\alpha$-globin, and/or protein stability, remains unknown and may depend on the mouse strain. In vitro, the human cell genotype and the culture system may also make a difference. Therefore, the only way to compare vector efficiencies is to test the vectors in parallel. Studies of this type have been performed with vectors containing identical LCR elements, making it possible to improve vector prototypes $[62,74,93,100]$, but rarely with LVVs developed by different research groups. One exception is the CCL- $\beta$ AS3-FB vector from Kohn's team, which has been compared with both $\mathrm{V} 5 \mathrm{~m} 3-400$ [101] and GLOBE-AS3 [94], these three LVVs being derived from three different prototype vectors (Figure $1)$. The V5m3-400 and CCL- $\beta A S 3-F B$ LVVs yielded equivalent infectious titers and transgene expression levels [101], whereas GLOBE -AS3 had a titer about four times higher than that of CCL- $\beta$ AS3-FB [102]. Furthermore, at a similar multiplicity of infection (MOI), the CCL- $\beta A S 3-F B$ had a 2.4-fold lower transduction efficiency in hematopoietic $\mathrm{CD} 34^{+}$cells than GLOBE -AS3. However, these weaknesses were counterbalanced by a higher level of transgene expression with CCL- $\beta$ AS3-FB than GLOBE -AS3 at equal VCN [103]. The two vectors may therefore be considered to work equally well on a per infectious particle per $\mathrm{CD}_{3} 4^{+}$cell basis. The CCL- $\beta$ AS3-FB makes it possible to obtain therapeutic gene expression with a lower VCN, making the vector safer. Conversely, the GLOBE -AS3 vector is produced at a higher titer and transduces primary $\mathrm{CD} 34^{+}$cells more efficiently. The production cost is therefore likely to be lower. Recent refinement of the LCR core HS elements from the CCL$\beta A S 3-F B$ vector have made it possible to reduce the total size of the vector by $2.1 \mathrm{~kb}$, and to increase its titer and transduction rate, but at the expense of decreasing therapeutic gene expression in erythroid cells [99], bringing the properties of this new vector (CoreGA-AS3-FB) closer to those of GLOBE -AS3. Overall, a number of LVVs, encoding $\beta^{A}, \beta^{A-T 87 Q}, \beta^{A S 3}$, or $\gamma$-globin chains and developed and tested in vitro and in animal models $[70,74,93,102,104-108]-$ HPV569, TNS9.3.55, BB305, GLOBE, sG ${ }^{\mathrm{b}} \mathrm{G}, \mathrm{CCL}-\beta A S 3-\mathrm{FB}$, and GLOBE-AS3 (Figure 1) - have been or are being evaluated in clinical trials in humans (Figure 2).

\subsection{Artificial miRNA targeting a suppressor of fetal hemoglobin}

An alternative strategy for the treatment of $\beta$ hemoglobinopathies is based on reactivation of the endogenous fetal $\gamma$-globin gene, effectively reversing the fetal-to-adult hemoglobin switch. Given that the hemoglobin switch functions like a rheostat, activation of the fetal globin gene leads to concomitant downregulation of the disease-causing $\beta^{s}$ chain. This basic strategy is decades-old, but the lack of knowledge concerning the cellular factors governing the switch precluded the development of therapeutic approaches based on this mechanism. The rise of highthroughput genome sequencing and population genetics in the $21^{\text {th }}$ century, together with the availability of high-quality phenotypic information has led to the identification of several crucial factors involved in the fetal-to-adult hemoglobin switch [109113]. The transcription factor $B$ cell CLL/lymphoma 11A (BCL11A), a potent developmental stage-specific repressor of $\gamma$-globin, emerged from genome-wide association studies (GWAS) of individuals with high baseline levels of HbF. BCL11A is unusual among the factors initially discovered in that it seems to have no crucial function in erythrocytes other than regulation of the hemoglobin switch, whereas it has major indispensable functions in other hematopoietic lineages, such as B-cell progenitors [114, 115]. The first therapeutic approach to harness this knowledge by targeting and downregulating $B C L 11 A$ to induce $\mathrm{HbF}$ production was developed shortly after these discoveries were made. A LV gene therapy vector expressing a small hairpin RNA (shRNA) for the downregulation of $B C L 11 A$ was initially generated. It yielded high levels of $\mathrm{HbF}$ induction in vitro, but transplantation experiments in mice were unsuccessful due to the near-complete loss of HSCs 
carrying the modified gene [116-118]. Multiple modifications were introduced to address several shortcomings of this initial construct. BCL11A knockdown-related toxicity in non-erythroid lineages, specifically in HSCs and the B-cell lineage, was prevented by replacing the simple ubiquitously active polymerase III-driven shRNA with a microRNA mimic (shRNA ${ }^{\text {miR }}$ ) under the control of erythroid cell-specific polymerase II-driven transcriptional regulatory elements identical to those used for LVV-mediated $\beta$ like globin expression (HS2/HS3/ $\beta$-globin promoter). The resulting construct downregulated BCL11A selectively in erythroid cells, efficiently induced $\mathrm{HbF}$ and largely attenuated the hematologic effects of SCD $[117,119]$. This vector entered a phase I clinical study in 2018 at Boston Children's Hospital and highly promising initial results were presented at the annual American Society of Hematology meeting: therapeutic efficacy exceeded that reported for other approaches at similar vector copy numbers [120] (see clinical trial results below).

Combination of shRNA ${ }^{\text {mir }}$ mediated BCL11A knockdown with the recombinant expression of antisickling globin variants, such as $\beta^{\mathrm{AS3}}$ or $\beta^{\mathrm{T} 87 \mathrm{Q}}$, encoded by the same vector is an appealing idea. Hairpin shRNAs and globin transgenes can, potentially, be expressed under the control of the same promoter, and the presence of intervening sequences 1 and 2 in globin vectors facilitates the positioning of the hairpin sequence within the introns of the globin transgene. The resulting vector structure and the molecular processing steps of the mRNA are complex, but, theoretically, the intronic shRNA ${ }^{\text {miR }}$ can be excised and processed by the Microprocessor complex in the nucleus with no negative effect on globin transgene expression. This approach will probably prove to be the most effective yet, in terms of therapeutic efficacy per integrated vector copy, but the complex structure and size of the vector may limit the generation of high viral titers, as reported for lentiviral vectors harboring large transcriptional control segments[99].

\subsection{Gene editing}

Recent advances in genome editing technologies, based on clustered regularly interspaced short palindromic repeats (CRISPR) RNA-guided nucleases (CRISPR/Cas), or customized engineered zinc-finger (ZFNs) or transcription activator-like effector (TALENs) nucleases, have made it possible to modify the genome in a targeted manner in many cell types and organisms. The nucleases introduce double-strand breaks (DSBs) at a specific site, which are then repaired via two competitive cellular repair pathways: non-homologous end joining (NHEJ), and homologydirected repair (HDR) [121].

Theoretically, the correction of diseasecausing mutations through HDR with a designer nuclease and a DNA template is the ideal approach, as it can restore normal $\beta$-globin function while ensuring physiological and high levels of $\beta$-globin gene expression [122-132]. This strategy avoids the risk of insertional mutagenesis associated with LVVmediated gene transfer, and is particularly suitable for the Glu6Val mutation affecting millions of patients with SCD. One study reported a very high frequency of Glu6Val correction, ranging from 30 to $70 \%$ in $\mathrm{CD} 34^{+}$ cells, following electroporation with the Cas9/gRNA complex followed by the delivery of a homologous DNA template by an adeno-associated virus serotype 6 (AAV6) [131, 133]. However, the level of correction in long-term HSCs was lower than that in $\mathrm{CD}_{3} 4^{+}$cell pools, by a factor of 5 to 20 [131], confirming that HSCS are more resistant to HDR than committed progenitor cells $[128,131,134]$.

A single editing system is required for $S C D$, but a number of specific nuclease/guide RNA complexes must be designed and optimized to deal with the diversity of point mutations and deletions in $\beta$ thalassemia. The effort required may be too great for clinical applications aimed to reverse point mutations. The targeted integration of a functional copy of the $\beta$ globin gene into the beta-globin locus has, therefore, been studied as a universal therapeutic approach for $\beta$-hemoglobinopathies. Dever et al. reported a gene addition system, in which the therapeutic $H B B$ CDNA was inserted within exon 1 of a mutated $H B B$ allele, such that expression was controlled by the endogenous $\beta$-globin LCR and promoter. The mean targeting efficiency was $11 \%$ in adult $\mathrm{CD}^{4} 4^{+}$cells following the AAV6-mediated delivery of a donor cassette carrying the functional $H B B$ cDNA plus a selection gene, and a gRNA/Cas9 RNP complex targeting the $H B B$ gene. The initial correction efficiency was not high, but an enrichment in cells with edited genes of up to $\approx 90 \%$ could be obtained in longterm HSCs, with the selection marker [131]. This system has the potential to enrich HSC preparations in cells with edited genes, but it remains to be determined whether engraftment levels will be sufficiently high to sustain hematopoietic reconstitution permanently in humans.

The coinheritance of HPHF with $\beta$-globin gene mutations is associated with mild clinical symptoms of 
$\beta$-hemoglobin disorders. Therefore, the introduction of a natural HPFH mutation by HDR, mimicking the $\mathrm{HPFH}$ phenotype, is being considered as an alternative genome editing option applicable to both SCD and $\beta$ thalassemia. Several point mutations and small deletions in the ${ }^{A} \gamma$ - or ${ }^{G} \gamma$-globin gene promoters resulting in an increase in $\mathrm{HbF}$ levels to more than $30 \%$ in adults have been reported [135-147]. Introduction of the naturally occurring $-175 \mathrm{~T}>\mathrm{C}$ HPFH mutation into the ${ }^{A} \gamma$-globin promoter has been shown to increase $\mathrm{HbF}$ production significantly in the $\mathrm{K} 562$ erythroid cell line [148]. The introduction of point mutations 115 and $200 \mathrm{bp}$ upstream from the transcription start site, within binding sites for the fetal globin gene repressors $B C L 11 A$ or zinc-finger- and BTB-domaincontaining 7A (ZBTB7A, also known as LRF), respectively, led to high levels of $\mathrm{HbF}$ production in the HUDEP-2 immortalized erythroid progenitor cell line [149]. A recent study revealed that introducing the natural $-113 A>G$ HPFH mutation into the ${ }^{A} \gamma$-globin promoter increased HbF levels in HUDEP-2 cells to potentially therapeutically relevant levels. The increase in $\mathrm{HbF}$ production did not disrupt BCL11A binding, but probably resulted from the de novo creation of a binding site for the GATA-1 master erythroid transcription activator [150]. Further investigations of the efficacy of these approaches are required, in clinically relevant cell types. Furthermore, as NHEJ predominates over HDR in quiescent HSCs, a careful evaluation of correction will be required in these cells. The various editing systems using nucleases as well as the methods for co-delivery of the DNA repair template should be compared in terms of their ability to trigger HDR, the frequency of which will need to exceed that of the more error-prone NHEJ [133]. The identification of compounds that enhance HDR and/or inhibit NHEJ will be a great challenge in attempts to improve gene editing via HDR in HSCs and to bring HDR-based therapeutic applications closer to clinical practice. An additional challenge for clinical development will be the expansion of HSCs with edited genes if the selection of edited cells is required due to limited HDR efficacy. This limited efficacy of HDR in hematopoietic stem cells can be accounted for by the limitation of the repair mechanism to the $\mathrm{S} / \mathrm{G} 2$ phases [151]. By using a modified version of Cas9 with lower levels of nuclease activity in the G1 phase of the cell cycle, in which HDR cannot occur, and transiently increasing the proportion of cells in the phases in which HDR preferentially occurs (S/G2), Lomova and coworkers managed to increase the HDR/NHEJ ratio four-fold over the control condition [152]. It remains to be determined whether this treatment does not affect the ability of cells to reconstitute human hematopoiesis.

The introduction of insertions and/or deletions (INDELs) through mechanisms involving DSB repair by the NHEJ pathway can be used as an indirect approach for creating naturally occurring HPFH deletions in HSPCs and inducing $\mathrm{HbF}$, to improve SCD and $\beta$-thalassemia phenotypes [153-156]. This approach yielded high level $\gamma$-globin expression in human primary cells grown in vitro [157]. The transplantation of a CRISPR-Cas9-edited HSCenriched population with a targeted deletion of the BCL11A binding site in the ${ }^{\mathrm{A}} \gamma$-globin gene promoter in nonhuman primates was recently shown to lead to sustained $\mathrm{HbF}$ reactivation in 6 to $18 \%$ of the red blood cells of these animals [158]. However, it remains to be seen whether the survival advantage conferred on corrected erythroid cells and the amount of $\mathrm{HbF}$ produced per cell are sufficient to improve the phenotype of SCD or TDT patients. Indeed, due to the strong homology and the proximity of the two $\gamma$-globin genes, $H B G 1$ and $H B G 2$, the simultaneous DSBs of both promoters by nucleases can result in the deletion of HBG2 [159] and the HBG intergenic region, and thus reduce the overall expression of therapeutic $\mathrm{HbF}$ in edited cells. The most advanced pipeline currently available for NHEJ-mediated disruption to treat $\beta$ hemoglobinopathies targets the erythroid cell-specific enhancer in the BCL11A gene. As in the shRNA ${ }^{\text {miR }}$ mediated knockdown approach targeting $B C L 11 A$, the resulting downregulation of the BCL11A protein is limited to the erythroid lineage and spares all other cell types, thereby preventing undesirable side effects. Multiple critical enhancer sites have been identified within intron 2 of $B C L 11 A$, initially by GWAS, with subsequent characterization at single-nucleotide resolution with high-density functional CRISPR screens $[160,161]$. A specific GATA-1 binding site at the $+58 \mathrm{~kb}$ position has been shown to be responsible for the erythroid cell-specific upregulation of $B C L 11 A$, and even single-base pair deletions within this binding site strongly decrease $B C L 11 A$ expression and induce $\gamma$ globin production as effectively as larger deletions, demonstrating that most of the function is contained within this small functional DNA element [162]. CRISPR/Cas9-mediated disruption of this site in human HSCs, with ribonucleoprotein (RNP) delivery, resulted in very high editing rates (about $90 \%$ ) and an induction of fetal globin to levels of $\sim 50-60 \%$ total hemoglobin, 
well above the range required for therapeutic efficacy, and similar to those reported for shRNA-mediated knockdown in in vitro assays [117].

Several gene editing approaches for treating hemoglobinopathies are already being explored by biotech and pharmaceutical companies: Sangamo Therapeutics is assessing ST-400, Bioverativ BIVV003, Vertex/CRISPR Therapeutics CTX001, Editas Medicine EDIT-301, Intellia Therapeutics OTQ923, and Shanghai
Bioray Laboratory is assessing autologous HSCs in which $\gamma$-globin has been reactivated and autologous HSCs in which $\beta$-globin expression has been restored. The base editing strategy (see "ALTERNATIVE DIRECTIONS" below) is being tested by Beam Therapeutics for SCD and TDT. Induced hematopoietic stem cell technology (iHSC) is being developed by Allife Medicine.

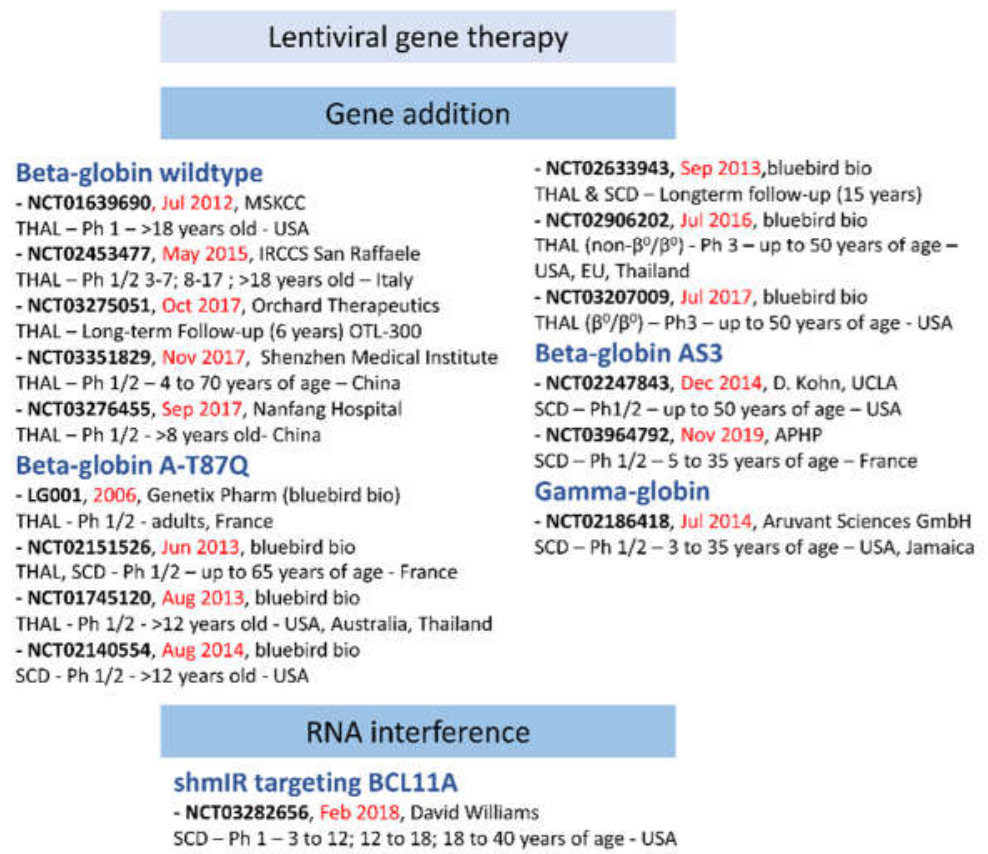

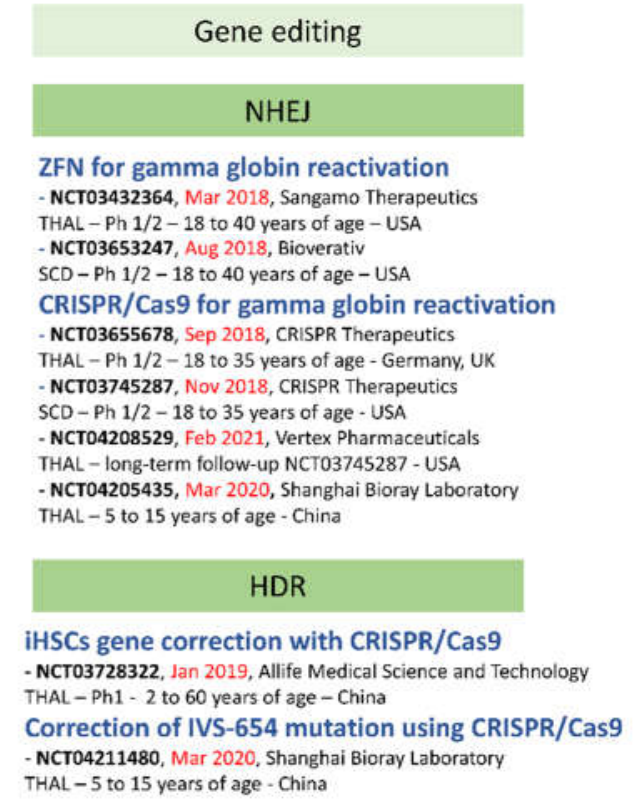

Figure 2: Clinical trials of gene therapy for $\beta$-hemoglobinopathies APHP: Assistance Publique - Hôpitaux de Paris; MSKCC: Memorial Sloan Kettering Cancer Center ; CRISPR/Cas9: Clustered Regularly Interspaced Short Palindromic Repeats / CRISPR Associated protein 9 ; GmbH: Gesellschaft mit beschränkter Haftung ; HDR: Homology-Directed Repair ; NHEJ: Non-Hhomologous End Joining ; SCD: Sickle Cell Disease ; THAL: $\beta$-thalassemia ; UCLA: University of California, Los Angeles ; ZFN: Zinc Finger Nuclease.

\section{CLINICAL STUDIES}

Several gene therapy programs for beta-hemoglobin disorders are already implemented in clinical practice. A brief description of each clinical trial is available from clinicaltrials.gov, and data from some of the studies have been published in peer-reviewed journals. A brief overview of the clinical applications is provided in figure 2 . The approach used involves the autologous transplantation of HSCs genetically modified ex vivo with LVVs carrying a transgene under the control of an erythroid cell-specific promoter and enhancer. The transgene can encode the wildtype $\beta$ globin or mutated versions to provide particular properties, such as anti-sickling $\left(\beta^{\mathrm{A}-\mathrm{T870}}, \beta^{\mathrm{AS} 3}\right)$. Alternatively, the transgene may encode a $\gamma$-globin chain or be replaced by an shRNA targeting a repressor of $\gamma$-globin (e.g. shRNA miR BCL11A). A Phase I clinical trial for the treatment of TDT with autologous CD34 ${ }^{+}$ cells transduced with the TNS9.3.55 lentiviral vector encoding the normal human beta-globin was initiated in New York City, at Memorial Sloan Kettering Cancer Center, in July 2012, by the groups of Michel Sadelain and Isabelle Riviere (NCT01639690). The first was a 23year-old woman who underwent peripheral blood stem cell mobilization with filgrastim. Her CD34 ${ }^{+}$cells were transduced with the LVV and the mean VCN in bulk $\mathrm{CD}^{+} 4^{+}$cells was 0.39 copies per cell. The nonmyeloablative conditioning was well tolerated and rapid engraftment was observed[163]. Three additional subjects were treated and displayed stable engraftment. The treatment was well tolerated but 
the patients did not achieve transfusion independence [164].

The first successful gene therapy for $\beta$ hemoglobinopathies in France was performed with the vector developed by the group of Philippe Leboulch in the LG001 clinical trial[98]. An adult patient with severe $\beta^{\mathrm{E}} / \beta^{0}$ thalassemia became transfusion-independent after full myeloablative conditioning with busulfan and the autologous transplantation of HSCs genetically modified with the SIN LVV HPV569 encoding the $\beta^{\text {A-T87Q }}$-globin gene. The $2 \times 250$ bp insulator was unstable, and one of the two cores was lost in a large proportion of integrated vectors. Partial clonal dominance, which subsided over time and subsequently declined was observed upon vector integration into the HMGA2 gene [165]. An analysis of the integrated vector revealed transcriptional activation of the HMGA2 gene in erythroid cells and abnormal splicing of the endogenous HMGA2 RNA. Retrospective analysis showed that blood $\mathrm{Hb}$ levels remained stable, at about $8.5 \mathrm{~g} / \mathrm{dL}$, for more than eight years [166]. A nextgeneration LentiGlobin vector (BB305) was designed to remove the unstable insulator sequence and the titer was increased with a CMV hybrid LTR [74]. These changes increased vector titers ( 3 to 4-fold) and transduction efficacy (2 to 3-fold). Patients in France were treated with this new LVV (NCT02151526), and clinical trials were extended to other European countries (NCT02906202), the USA (NCT02140554, NCT03207009), Australia (NCT01745120) and Thailand (NCT01745120, NCT02906202). The first improvement in SCD phenotype following gene therapy was reported in 2017 for the first patient treated with BB305 [167]. The level of therapeutic anti-sickling beta-globin remained high (approximately 50\% of beta-like globin chains), with correction of the biological hallmarks of the disease. In 2018, the potential of BB305 to treat TDT was demonstrated in 22 patients [168]. Autologous transplantation with $\mathrm{CD} 4^{+}$cells transduced with the BB305 LVV eliminated or reduced the need for red blood cell transfusions. Patients from the various clinical trials will be monitored for 15 years, in a long-term follow-up protocol (NCT02633943).

Another LVV encoding the normal human $\beta$ globin (GLOBE) was developed by the group of Giualina Ferrari in Italy. A Phase I/II clinical trial sponsored by IRCCS San Raffaele was initiated in May 2015 (NCT02453477). The design of this study involved the successive enrollment of three groups of
TDT patients: three adults ( $\geq 18$ years old), three older children (8-17 years old) and four younger children (under the age of 8 years). Intraosseous autologous stem cell transplantation was performed. Interim data were reported in February 2019, after the treatment of three adults and six children [169]. Rapid hematopoietic recovery with multilineage polyclonal engraftment was achieved. The mean VCN ranged from 0.1 to 1.97 in erythroid precursors one year posttreatment. No clonal dominance was observed. Transfusion requirement decreased in adults, and three of the four younger children treated were transfusion-independent at the time of the publication. The NCT03275051 long-term follow-up study is sponsored by Orchard Therapeutics.

A trial of a LVV encoding a $\gamma$-globin chain, sponsored by Aruvant Sciences $\mathrm{GmbH}$, was initiated in July 2014. For eligibility, subjects had to have an $\mathrm{HbS} \beta^{0}$-thal, $\mathrm{HbS}^{+}$-thal or HBSS SCD genotype. Bone marrow or mobilized $\mathrm{CD} 34^{+}$cells were transduced ex vivo and infused into the patient after reducedintensity chemotherapy conditioning with single-dose melphalan. The treatment of two patients with the $\mathrm{HbS} \beta^{0}$-thal genotype was reported in 2018. The first patient received $1 \times 10^{6} \mathrm{CD} 34^{+}$cells/kg with a VCN of 0.22 , and the second patient was treated with $6.9 \times 10^{6}$ $\mathrm{CD} 4^{+}$cells/kg with a VCN of 0.46 [170]. the time-toneutrophil engraftment was nine days for the first patient, and seven days for the second patient, and reconstitution was highly polyclonal. Only a few results are available: a proportion of $20 \%$ was reported for the modified $\mathrm{HbF}$ (produced from the transgene) in the blood of the first patient $(2.1 \mathrm{~g} / \mathrm{dL}$ modified $\mathrm{HbF}$ in $10.6 \mathrm{~g} / \mathrm{dL}$ total $\mathrm{Hb}$ ) one year after treatment.

Two clinical trials are being conducted with $\beta^{\text {AS3 }}$-globin LVVs (NCT02247843 [171] and NCT03964792) but no data have yet been published.

A LVV carrying an anti-BCL11A shRNA ${ }^{\text {mir }}$ (microRNA-adapted short hairpin RNA) expressed under the control of the $\beta$-globin promoter and LCR elements (HS2 and HS3) has been developed by the group of David Williams in Boston. This vector is designed to induce the expression of endogenous $\gamma$ globin genes, by downregulating the transcriptional repressor BCL11A. In preclinical studies, $\mathrm{CD} 34^{+}$cells from healthy donors or donors with $S C D$ were transduced with GMP-grade LVV. A high VCN (>5) and high levels of gene marking (>80\%) resulted in a threeto five-fold induction of $\mathrm{HbF}$ with no effect on cell growth or differentiation [119]. A clinical trial was 
initiated in 2018, on the infusion of autologous CD34 cells transduced with the LVV after nearmyeloablative conditioning with busulfan. Eight patients, aged 7 to 36 years, all with an HbSS genotype, were enrolled in the trial [172]. Initial results for the first five patients, with a maximum follow-up of 18 months, were reported at the ASH meeting in 2019 [172]. Rapid engraftment was observed in all patients; there were no severe adverse events related to the vector, and HbF levels in this patient cohort ranged from $23 \%$ to $43 \%$ of total hemoglobin. The fraction of F-cells was consistently between $65 \%$ and $75 \%$ and remained stable over time at vector copy numbers of $0.4-1.6$ per cell.

Clinical trials of gene editing for TDT and SCD are also underway and will provide data relating to the safety and efficacy of this non-viral strategy. ST-400 is an ex vivo gene-edited cell therapy for TDT developed by Sangamo Therapeutics. This autologous cell therapy involves the editing of the BCL11A gene in HSCs from the patient with ZFN technology (NCT03432364). Erythroid colony genotyping showed biallelic modification of the BCL11A erythroid enhancer in $>50 \%$ of progenitors, resulting in an increase in $\gamma$-globin mRNA and protein levels to values more than four times those in the controls [173]. No patient follow-up data have yet been published. Four clinical trials involving the use of the CRISPR/Cas9 system to reactivate $\gamma$-globin through a similar strategy are still underway. CRISPR Therapeutics initiated clinical trials in 2018 in Europe (NCT03655678) for TDT and in the USA (NCT03745287) for SCD. Shanghai Bioray Laboratory is sponsoring two clinical trials in China. The NCT04205435 trial is a study including up to 12 participants with TDT. Its objective is to evaluate the safety and efficacy of treatment with autologous HSCs in which $\gamma$-globin has been reactivated with the CRISPR/Cas9 gene editing system. The NCT04211480 trial is designed to determine the safety and efficacy of autologous HSCs in which $\beta$-globin expression has been restored, in TDT patients with the IVS-654 mutation. $\beta$-globin expression will be restored in autologous HSCs with the CRISPR/Cas9 gene editing system. No results have yet been reported.

One clinical trial is using the CRISPR/Cas9 system to correct the genome of iHSCs (see section 4.1, third paragraph). It is sponsored by Allife Medical Science and Technology (NCT03728322) and was initiated in January 2019 [174]. No results have yet been published.
The first gene therapy product reached the market in June 2019 [175]. In a press release, Bluebird Bio announced EU conditional marketing authorization for Zynteglo ${ }^{\mathrm{TM}}$ (autologous $\mathrm{CD}^{+} 4^{+}$cells encoding the $\beta^{A-T 87 Q}$-globin gene) gene therapy for patients aged 12 years or over with transfusiondependent beta-thalassemia and a genotype other than $\beta^{0} / \beta^{0}$. The large number of clinical trials underway or soon to be initiated is a source of hope that new gene therapy products will become available very soon.

\section{ALTERNATIVE DIRECTIONS}

\subsection{Induced pluripotent stem cells}

Gene therapy protocols would be greatly improved if an expansion phase were possible for the corrected cells before their transplantation, but the challenge of expanding HSC populations ex vivo or, at least, maintaining their stemness properties during their correction, has slowed progress. Induced pluripotent stem cells (IPSCS) have unlimited self-renewal and proliferation capacities, they can be genetically modified and selected, and they can differentiate into various mature cell types [176]. They therefore represent a potential alternative source of cells for regenerative medicine.

The first proof-of-concept for the treatment of SCD with IPSCs was obtained in 2007 [177]. IPSC generation and gene electroporation were combined, and the SCD mouse model was corrected by the transplantation of hematopoietic progenitors derived from the corrected IPSCs. Progress has since been made toward the targeting of point mutations in IPSCS derived from patients suffering from SCD, with ZFNs [178], TALENs [179], CRISPR/Cas [127, 180]' [181]. However, none of these IPSCs were evaluated for clinical potential after transplantation. IPSCs from $\beta$ thalassemia patients have been successfully generated and corrected by homologous recombination [182] or gene addition [183, 184], and the functionality of these cells has been demonstrated by in vivo transplantation in immunodeficient mice. However, these studies reported very low rates of hematopoietic reconstitution. More recently, integration-free IPSCs have been obtained from patients with $\beta$-thalassemia using non-integrative vectors, and HBB mutations have been corrected by a TALEN-based approach [185], ZFN-mediated gene therapy [186], or CRISPR/Cas9 technology [122, 187189]. In these studies, evaluations of the potential 
therapeutic effect of the correction were mostly based on the capacity of corrected IPSCs to differentiate in vitro but not in vivo. The transplantation into immunodeficient mice of human-derived and CRISPR/Cas9-corrected IPSCs led to the production of therapeutic hemoglobin, but only low levels of hematopoietic reconstitution [188].

IPSC reprogramming is based on the modification of somatic cells by transcription factors. Great progress has been made towards limiting the risk of tumors associated with this process through the use of non-integrative strategies $[185,190]$ or screening for safe harbor integration sites [183], but IPSC generation can lead to genomic instability [186, 187]. The mutation status and tumorigenic potential of these cells will therefore need to be thoroughly tested before their use in clinical practice [191]. The near-impossibility of generating large numbers of transplantable HSCs from IPSCs greatly hampers the use of these cells in clinical practice. Daley's group has worked on re-specification, a strategy for reverting IPSC-derived hematopoiesis-committed progenitors to a more immature state for the generation of induced HSCs (iHSCs), for expansion in vitro and with multipotent engraftment potential in vivo. Depending on the combination of transcription factors used, the iHSCs support short- [192] or long-term [193] hematopoietic reconstitution. Respecifying IPSCs, to generate engraftable iHSCs, is a promising approach to the testing of gene therapy strategies through assessments of the correction of human cells in in vivo models of human diseases, but the generation of functional and safe HSC populations that can be expanded to the clinical scale for engraftment in patients with no loss of differentiation capacity or safety may still be a long way off.

\subsection{Base and prime editing}

Engineered genome-editing nucleases create doublestrand breaks (DSBs) that are then repaired by one of the two main repair mechanisms of cellular DNA: nonhomologous end-joining (NHEJ) or homology-directed repair (HDR). At the target site, in the presence of the correcting homologous DNA template, HDR competes with NHEJ during the resolution of DSBs (Figure $3 \mathrm{~A}$ ). This is particularly problematic in non-dividing cells, such as HSCs, because HDR is mostly restricted to the S/G2 phases of the cell cycle [194]. As a result, gene correction rates are low in primary HSCs. DSBs can, thus, generate small insertions, deletions or point mutations [184], large deletions [195] and chromosomal truncations [196], at the target site, and at more distant locations. These undesired on- and offtarget effects constitute a major challenge to the efficient and safe use of CRISPR/Cas systems for correcting genetic diseases in clinical practice. In this context, attempts to circumvent DSBs during gene editing have resulted in the recent development of alternative approaches that do not rely on HDR (discussed in [197-199]).

\subsubsection{Base editing}

Engineered base editors can convert one base pair into another at a target site without generating DNA DSBs, resulting in lower rates of indel mutations than Cas9based HR methods at both on- and off-target sites [200-203]. The cytosine base editor (CBE) converts the C-G pair into a T-A pair. It has four components: a guide RNA (gRNA), a catalytically impaired Cas9D10A mutant, a cytidine deaminase domain from apolipoprotein B editing complex 1 (APOBEC1) or activation-induced deaminase (AID), and a uracil glycosylase inhibitor (UGI). The guide RNA-Cas9 ribonucleoprotein complex binds to its complementary DNA, and the cytidine deaminase domain then converts cytidine residues into uridines within a window of five nucleotides around the target DNA. The UGI domain prevents the action of the base excision repair (BER) pathway, thereby preventing the reversion of the obtained U-G mismatch to C-G. Cas9 ${ }^{\mathrm{D} 10 \mathrm{~A}}$ cleaves the complementary strand, thereby guiding the mismatch repair (MMR) system to the unedited nicked strand, using information from the edited template. Replication or repair mechanisms then mediate the conversion of uridine into thymidine, and permanently convert the $\mathrm{C}-\mathrm{G}$ pair into a T-A pair [201-203] (Figure 3B). Gaudelli and coworkers created an adenosine base editor ( $A B E)$, in which the cytosine deaminase is replaced by an engineered enzyme that can transform adenine into inosine, facilitating the highly efficient conversion of A-T to G-C pairs in human cells [200]. These targeting strategies are promising for the treatment of diseases caused by single-nucleotide polymorphisms. However, the use of these base editors induces indels, albeit at a lower frequency than CRISPR/Cas9 associated with DNA donor template [200, 202]. In mouse embryos, unexpected conversions or indel mutations are frequently observed at the target site of CBE [204]. Recent findings have shown that off-target singlenucleotide variants (SNV) are limited but present in cell lines [205], mouse embryos [206] and rice cells [207], in experiments using CBE [206, 207], and ABEs [205]. Furthermore, thousands of SNVs have been 
identified in RNA transcripts. They have been detected in oncogenes and tumor suppressor genes, raising concerns about the oncogenic risk associated with the use of base editors [208-210]. CBE variants involving alternative and engineered cytidine deaminases, developed to increase the precision and efficiency of on-target editing and to reduce off-target mutations, have been tested for the correction of a mutation frequently found in the $\beta$-globin promoter of Southeast Asian patients with $\beta$-thalassemia. They efficiently corrected the targeted mutation, but unwanted on- and off-target SNVs were nevertheless detectable in human cells [211, 212]. Highly efficient CBE-mediated editing ( $>90 \%$ in some cases) has been achieved in the erythroid cell-specific enhancer of the $B C L 11 A$ gene and a $\beta$-thalassemia-associated promoter mutation in the HBB gene in human HSCs. This editing was associated with the induction of therapeutic levels of $\mathrm{HbF}$ ( $30-40 \%$ of total hemoglobin) in unselected cells in vitro and in humanized mice in vivo, with the detection of minimal off-target editing. These results highlight the rapid progress made and the therapeutic potential of this technology [162, 213].

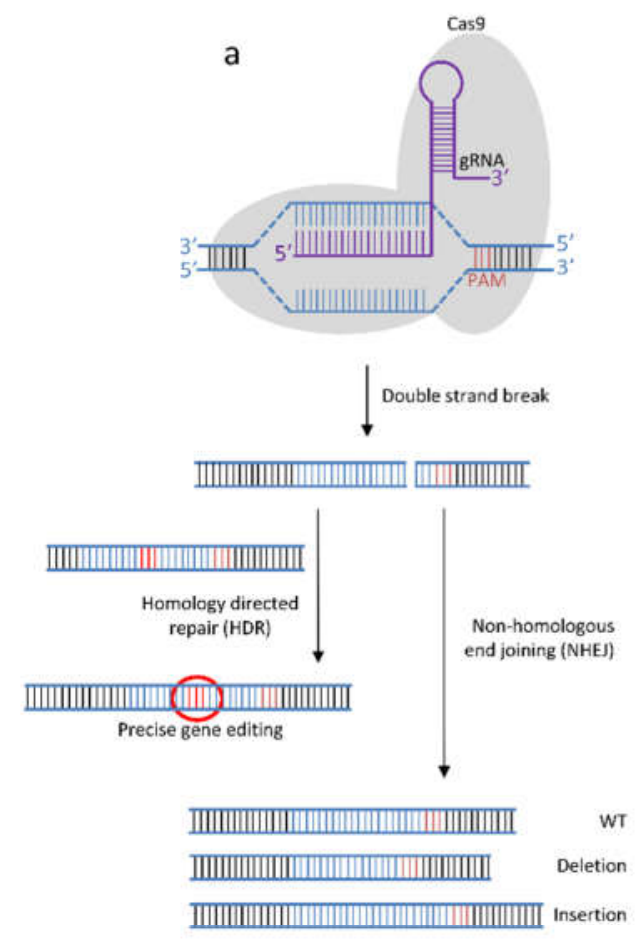

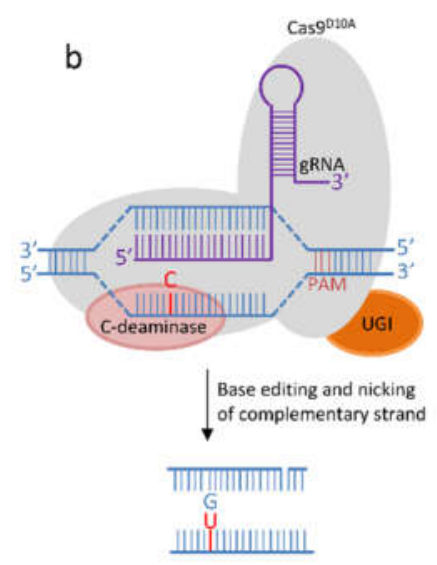

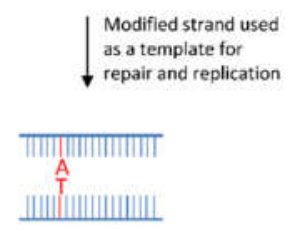

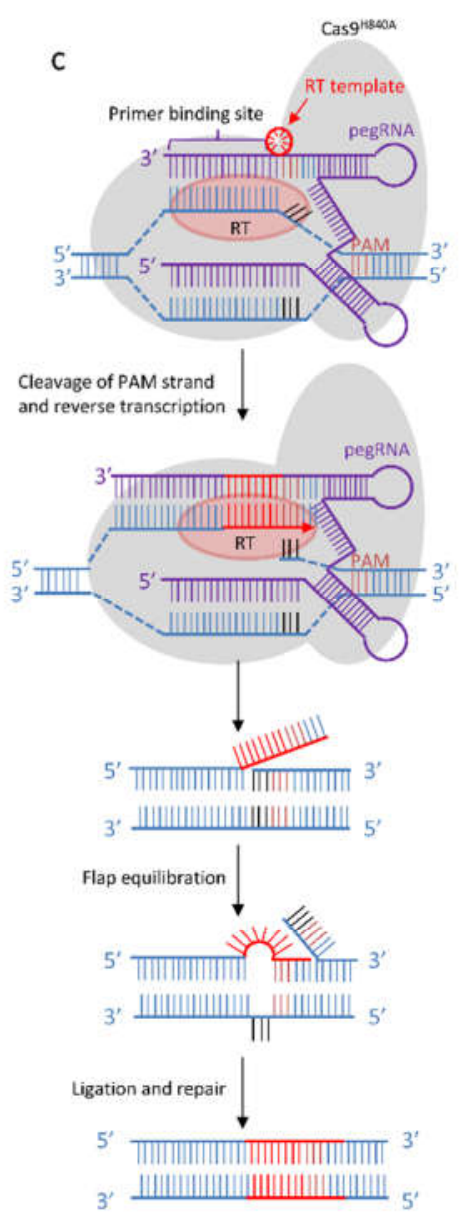

Figure 3: CRISPR-Cas9-mediated genome editing A) DNA double-strand break repair (DSB). gRNA directs the Cas9-RNA complex to its genomic target site and Cas9 breaks DNA three nucleotides upstream from the protospacer adjacent motif (PAM). The DSB is repaired by homologous recombination when a donor sequence with homology arms is provided, or by non-homologous end joining. Random insertions or deletions are then introduced. B) Base-editing system converting one base pair into another. The cytosine base editor (CBE) converts the $\mathrm{C}-\mathrm{G}$ pair into T-A. The guide RNA (gRNA) binds its complementary DNA, and cytidine deaminase (C-deaminase) then converts cytidine into uridine, leading to a U-G mismatch. The uracil glycosylase inhibitor (UGI) domain prevents reversion via the base excision repair pathway. Cas9D10A cleaves the complementary strand upstream from the PAM sequence and mismatch repair systems use the modified $\mathrm{U}$ base to correct the nicked strand. After replication and repair, the $\mathrm{G}-\mathrm{C}$ is thus converted into A-T. C) Prime editing allows all 12 base-to-base conversions. The prime editing (PE) complex consists of a reverse transcriptase (RT), a Cas9H840A enzyme and a guide RNA (pegRNA) that binds to the non-PAM strand, and specifically cleaves the PAM-containing strand. The primer binding site (PBS) of pegRNA binds to the cleaved strand, and the reverse transcriptase elongates DNA from the nicked 3 ' end, using its template. Flap equilibration allows the excision of one of the flaps by nucleases. When the $3^{\prime}$ DNA flap is not excised, ligation and DNA repair result in gene editing. 


\subsubsection{Prime editing}

A number of base conversions cannot be performed with base editors, including the T-A to A-T conversion required to correct $S C D$. The non DSB-mediated prime editing strategy can generate insertions, deletions and the 12 possible base-to-base conversions [214]. The prime editing complex has two components: the prime editor (PE), which consists of a reverse transcriptase (RT) fused to the $\mathrm{C}$ terminus of the mutant Cas9 ${ }^{\mathrm{H}}{ }^{\mathrm{AOA}}$ enzyme, and the prime editing guide RNA (pegRNA), which contains a binding site for the noncomplementary PAM strand (PBS), a RT template providing the desired edit, and a spacer sequence able to bind the non-PAM DNA target. The PAM strand is nicked by Cas $9^{\mathrm{H} 840}$ and the PBS hybridizes to the resulting $3^{\prime}$ end of the PAM strand. The reverse transcriptase elongates the nicked DNA strand from its $3^{\prime}$ end, using the RT template with the desired edit. There is then competition between the $3^{\prime}$ edited and $5^{\prime}$ non-edited DNA flaps. If the $3^{\prime}$ edited flap is excised by endonuclease, the sequence remains unchanged, but, if the $5^{\prime}$ non-edited flap is cleaved and the $3^{\prime}$ edited flap is ligated, edited DNA is obtained after DNA repair (Figure $3 \mathrm{C}$ ). Any mutation desired can be generated, with an efficiency of $\approx 33 \%$, with the most advanced prime editing technology. This system provides a solution complementary to base editors, with strengths and weaknesses specific to the targeted mutation. For example, the SCD mutation may be edited very efficiently in a cell line, but indel mutations are still observed at a high frequency, although lower than that observed with Cas9mediated HDR. Further studies are required to evaluate this system and to improve its accuracy.

\subsection{In vivo gene therapy}

In vivo gene therapy approaches would constitute a very interesting alternative to current gene therapy procedures, as they would avoid the need for both the myeloablative conditioning of patients and ex vivo correction of HSCs. Here, we discuss several in vivo gene therapy approaches that have given promising results in preclinical models, but for which long-term safety studies are required before transfer into clinical practice.

\subsubsection{Intraosseous injection of LVV}

Intraosseous (IO) injection targets vector delivery to the bone marrow, thereby increasing the likelihood of HSC transduction. In addition, the direct modification of HSCs has the advantage of keeping the cells in their physiological microenvironment. However, the lack of a specific marker for HSCs to allow their targeting, the phase of the cell cycle in which HSCs reside, the limited volume per injection, and the number of HSCs required for targeting pose obstacles to the development of this technique. In mice, the 10 injection of VSV-G pseudotyped LV particles has been reported to lead to only $2-3 \%$ of the peripheral blood cells being genetically modified [215]. This may be a sufficiently high level for hemophilia A [216] or Fanconi anemia [217], but it is too low for the correction of hemoglobin disorders [218, 219]. Viral particles pseudotyped with vesicular stomatitis virus glycoprotein (VSV-G) can enter almost any cell type, due to the omnipresence of VSV-G receptors [220], and these particles are highly sensitive to complement-mediated degradation mechanisms [221]. LVVs should therefore be engineered to target HSCs specifically and to be resistant to complement. In addition, activation of the $G_{0} / G_{1}$ transition would undoubtedly facilitate HSC transduction. To this end, LV particles carrying the complement-resistant engineered fusion protein RDTR instead of VSV-G, together with stem cell factor (SCF), have been produced [222]. They promoted highly efficient CD34 ${ }^{+}$ cell-targeted gene transfer in whole cord blood (CB) samples. In immunodeficient mice into which human $\mathrm{CB} \mathrm{CD} 34^{+}$cells had previously been injected, following inoculation of the femur with LV particles, the percentage of transduced human cells was much higher than with classical vector preparations, but nevertheless remained insufficient. LVV preparations contain proteins captured from the packaging cell lines that can induce alloimmune reactivity and limit vector survival. Genome editing in packaging cell lines for the production of alloantigen-free LVVs has been shown to enhance LVV stability and may help to increase efficacy after in vivo injection [223].

\subsubsection{Hybrid adenovirus/transposon system}

The access of HSCs to the bone marrow may be limited by the rigidity of the stroma and the limited space available for vector injection. Lieber's group aimed to increase transduction by developing an approach based on HSC mobilization and the intravenous injection of helper-dependent adenovirus (HD-Ad). Mobilization was achieved with a combination of GCSF and CXCR4 antagonists. The cells were then transduced with an HD-Ad5 $/ 35^{++}$vector system. Cell transduction with the $\mathrm{Ad} 5 / 35$ vector does not require cell division [224]. Chimeric Ad5 vectors carrying fibers from Ad serotype 35 further mutated into HD- 
Ad5 $/ 35^{++}$have no viral genes, preventing HSC cytotoxicity. Furthermore, they target cells expressing CD46 with high affinity [225]. This vector therefore combines efficient DNA delivery through binding to CD46, a receptor expressed on HSCs and highly abundant in the blood after mobilization, with the transduction of non-dividing cells. The integrating HDAd5 $/ 35^{++}$hybrid system developed by Lieber's group consists of an adenoviral helper vector providing the integrating machinery of the Sleeping Beauty (SB) transposon (HD-Ad-SB) and a transposon-donor adenoviral vector carrying the transgene (HD-Ad-Tg). An advantage of this transposase-dependent integration system is that it does not require the cellular DNA repair machinery and results in random integration. This system has been shown to modify 5 $10 \%$ of mouse HSCs in the long term, after peripheral blood cell mobilization and intravenous injection [226]. Vector genomes have been detected in the lung, liver, heart, and kidney, but this detection may reflect the infiltration of these organs with blood cells or the presence of residential macrophages. Further analyses are required to test this hypothesis.

\subsubsection{In vivo selection}

Given the high level of gene marking required for hemoglobin disorders, this approach has been associated with the in vivo selection of corrected cells based on insertion of the mutant $\mathrm{O}^{6}$-methylguanineDNA methyltransferase $\mathrm{MGMT}^{\mathrm{P} 140 \mathrm{~K}}$ gene together with the transgene [227]. The MGMTP ${ }^{140 K}$ gene allows for the in vivo selection of gene-bearing cells with low doses of $0^{6}$-benzylguanine $\left(\mathrm{O}^{6} \mathrm{BG}\right)$ plus bischloroethylnitrosourea (BCNU). A 12 kb DNA fragment consisting of the $\gamma$-globin $H B G 1$ gene, $4.3 \mathrm{~kb}$ of the $\beta$ globin LCR, a $0.7 \mathrm{~kb}$ promoter element, and a $\mathrm{MGMT}^{\mathrm{P} 140 \mathrm{k}}$ expression cassette is inserted into the transposon-donor vector. Following intravenous injection of the HD-Ad- $\gamma$-globin/MGMT and the HDAd-SB vectors into mobilized animals [228], $\gamma$-globin expressing RBCs were hardly detectable. However, after in vivo selection, up to $60 \%$ of red blood cells expressed the human $\gamma$-globin chain in the long term. In the $\mathrm{Hbb}^{\text {th } 3 / \text { th } 3}$ mouse model of thalassemia, even in the absence of MGMT-mediated selection, the percentage of $\gamma$-globin-expressing RBCs was higher than that in normal mice, thanks to the survival advantage conferred on the corrected red blood cells. After several cycles of $\mathrm{O}^{6} \mathrm{BG}$ and $\mathrm{BCNU}$ treatment, the level of corrected red blood cells reached $60 \%$, resulting in the near-complete correction of splenomegaly, hemosiderosis, and red blood cell parameters, despite low levels of $\gamma$-globin transgene expression ( $10 \%$ that in adult mouse globin genes). This system is of great interest, as it makes it possible to increase the size of the LCR further, thanks to the high cargo capacity of the vector $(\approx 30 \mathrm{~kb})$. Studies performed to date in large-animal models with the MGMT selection system have provided no evidence of a risk of carcinogenesis[229]. Nevertheless, the risks of triggering mutations due to the alkylating agent $\mathrm{BCNU}$ and the DNA repair inhibitor ${ }^{6} \mathrm{BG}$ in surviving selected HSCs, and those associated with the random integration of the vector, will require more complete evaluation in long-term studies.

\subsubsection{CRISPR/Cas9-mediated HDR}

With a view to improving the safety profile of in vivo HSC transduction, intravenous $\mathrm{HD}-\mathrm{Ad} 5 / 35^{++}$vectors have been used to provide a CRISPR/Cas9 complex generating DSBs at the AAVS1 locus, together with a donor template incorporating the $\gamma$-globin-MGMT DNA cassette flanked by AAVS1 homology arms and target sites for the AAVS1 CRISPR/Cas9 gRNA [230]. The use of this helper-dependent HD-Ad5 $/ 35^{++}$vector with a modified capsid to transduce mobilized HSCs, followed by in vivo selection, resulted in a high frequency of targeted integration in long-term HSCs. Interestingly, $\gamma$-globin expression levels were twice those obtained with the transposase-dependent system for similar numbers of integrated transgene copies per cell. However, on-target deletion and offtarget integration events were detected in this study. Given the potential rearrangements induced by CRISPR/Cas9 at the target site or distal to the cutting site [231], and the editing of large numbers of cells, such lesions may constitute a first carcinogenic hit. Long-term studies are required to determine whether cells with such deleterious chromosomal changes are removed by counterselection or become neoplastic over time. Furthermore, the need to eliminate a large part of the stem cell reservoir due to the low infection efficiency before selection raises questions about the capacity of the remaining cells to ensure hematopoiesis for the rest of the patient's life. This is also an issue for patients treated with ex-vivo gene therapy after myeloablative conditioning.

\subsubsection{CRISPR/Cas9-mediated DSBs}

HSC mobilization followed by non-integrative HDAd5 $/ 35^{++}$vector injection has also been used for the temporary expression of CRISPR/Cas9 to edit BCL11A binding sites and reactivate $\gamma$-globin gene expression [232]. In mice transgenic for the human $\beta$-globin locus, 
the percentage of edited cells was limited to $5-10 \%$, but the advantage provided by the expression of $\gamma$ globin in the erythroid cells of patients with $\beta$ thalassemia or SCD should make this approach more efficient in this context. The prolonged expression and/or activity of nucleases may be detrimental to HSCs in the long term [233-236]. Solving the problem of nuclease toxicity to HSC will be important not only in the context of in vivo gene therapy, but also for the ongoing HSC gene therapy approaches involving CRISPR/Cas9-mediated DSBs.

\subsubsection{PNA-mediated gene editing}

Another in vivo gene editing approach is based on triplex-forming peptide nucleic acids (PNAs). PNAs bind DNA in a site-specific manner, via strand invasion and the formation of a PNA/DNA/PNA triplex, through both Watson-Crick and Hoogsteen binding. The PNAs then recruit DNA repair systems to correct the genome with the desired sequence, co-delivered as a template. As PNAs involve high-fidelity DNA repair pathways and have no intrinsic nuclease activity, their use is less prone to indel mutations and/or chromosome rearrangements than current approaches based on nucleases. However, their in vivo delivery remains challenging. The extent of in vivo correction was recently evaluated in a mouse model of $\beta$-thalassemia transduced with a human $\beta$-globin gene with a splicing mutation in intron 2 (IVS2-654) [237]. The intravenous administration of MP $\gamma$ PNA (PNA with a mini polyethylene-glycol group) in poly(lactic-coglycolic acid) nanoparticles (PLGA NPs), associated with in vivo cKit ligand (SCF) treatment, led to gene editing in as many as $\approx 7 \%$ of early bone marrow progenitor cells, a level sufficiently high for partial reversal of the $\beta$-thalassemia phenotype. It remained unclear why SCF stimulated gene editing, and there is a need to determine whether this mechanism will operate in humans. $\gamma$ PNAs loaded into PLGA NPs have also been successfully used for genome editing in utero. There are several advantages to in utero gene therapy: HSCs are mostly proliferative and the fetal immune system is immature, allowing a better tolerance of delivery strategies. In utero gene editing would also fix the molecular defect before the appearance of the first symptoms and before the occurrence of irreversible damage in SCD or thalassemia. Furthermore, PLGA NPs have been approved for drug delivery applications [238] and their intravenous injection leads to their accumulation in the fetal liver [239], the site of hematopoiesis in the fetus. In this study, after a single treatment with PNAs and a donor template, in the absence of SCF injection, an editing frequency of $6 \%$ was observed in adult bone marrow cells, resulting in an improvement of the disease phenotype and the postnatal survival of $\beta$ thalassemic mice [239]. Almost no off-target mutations were detected, rendering this strategy potentially more attractive than nuclease-based technologies. More studies are required to assess the lack of specificity of non-viral delivery and the risk of germ cell mutation. In addition, further improvements in editing efficiency, to attain $20-30 \%$ modified cells, are thought to be required for the correction of hemoglobin disorders.

In vivo gene therapies limit the risk of losing the stemness and homing capability of HSCs due to the handling of these cells, and eliminate the need for myeloablative conditioning in patients with chronic diseases and preexisting organ damage. However, the translation of these technologies into clinical practice poses significant challenges. In vivo gene therapy protocols can activate innate and adaptive immune responses through the intravenous injection of the vector, and can lead to the transduction of cells other than HSCs. Many ethical issues have been raised regarding the use of these technologies, partly due to the risk of "off-target" effects on target cells, but also due to the risk of germ cell modification.

\section{CONCLUSION}

The results of recent clinical trials using LVVs to transduce HSCs for the treatment of $\beta$-thalassemia or sickle cell disease show very promising therapeutic efficacy. Several patients with no other hope of definitive treatment have been successfully cured of their chronic and debilitating hemoglobin disorder. These extremely convincing results have led the European Medicines Agency (EMA) to grant a conditional marketing authorization for Zynteglo, a gene therapy developed by the pharmaceutical company bluebird bio Inc., for the treatment of adult and adolescent TDT patients with the non $-\beta^{\circ} / \beta^{0}$ genotype, who are eligible for HSC transplantation, and for whom an HLA-matched donor is unavailable. One difficulty remains to be resolved: obtaining strictly reproducible and controllable results in all patients, including those with the most severe conditions ( $\beta^{0}$-thal for example), while maintaining a satisfactory safety profile. Efforts to achieve therapeutic benefit have, to date, focused on optimizing the rate of transduction and the intensity 
of myeloablative conditioning before the infusion of genetically modified HSCs, to maximize the number of vector copies per cell, and reach a mean VCN sufficient to achieve disease correction. This strong pressure on the transduction rate is a double-edged sword, because it increases the risk of insertional mutagenesis and, thus, of uncontrolled cell expansion and cell transformation. Insertional oncogenesis has not yet been observed with SIN LVVs, but remains a risk for which long-term assessment is required. Patients treated by gene therapy will be followed carefully for many years, with close scrutiny of the risks of cell transformation.

One of the major challenges in the last few years has been the delivery of LVVs to genomic sites devoid of oncogenes or sequences involved in the control of cell fate. The question of targeting LVVs to safe chromatin harbors was not addressed in this review, due to the lack of solid evidence that such an approach can work efficiently. Another possible way of reducing the risk of cell transformation would be to decrease the number of vector copies required per cell by increasing therapeutic efficacy. It may, therefore, be useful to develop vectors capable of expressing transgenes more strongly, or of delivering several genes together, each providing a specific and complementary therapeutic solution.

Alternatives to gene addition include targeted modifications through the use of nucleases or derivatives. The in vitro results obtained to date are very promising, and several clinical trials have already begun. The lack of hindsight makes it difficult to draw any firm conclusions about the efficacy and safety of these approaches as yet. They are also associated with an undeniable risk of mutagenesis. The challenge in the coming years will be to benchmark these methods and weigh up their respective risks and benefits [240]. There is no doubt that much research remains to be done in the field of gene therapy for hemoglobin disorders.

Author contributions This review article was written at the request of the editor. All authors participated in the literature review and writing of the manuscript. Emmanuel PAYEN critically revised and edited the manuscript.

Availability of data and material Not applicable

\section{DECLARATIONS}

Funding This work was supported with European Research Projects on Rare Diseases (GETHERTHAL) funding from the European Commission.

Conflicts of interest Olivier NEGRE is consultant for bluebird bio. He was a former employee and hare holder of bluebird bio. The other authors have on conflict of interest to declare.

Ethics approval Not applicable

Consent to participate Not applicable

Consent for publication All authors have read and approved the entire contents of the manuscript.

Code availability Not applicable

\section{REFERENCES}

1. Weatherall, D (2011). The inherited disorders of haemoglobin: an increasingly neglected global health burden. The Indian journal of medical research 134: 493-497.

2. Allison, AC (1954). Protection afforded by sicklecell trait against subtertian malareal infection. British medical journal 1: 290-294.

3. Piel, FB, Tatem, AJ, Huang, Z, Gupta, S, Williams, TN, and Weatherall, DJ (2014). Global migration and the changing distribution of sickle haemoglobin: a quantitative study of temporal trends between 1960 and 2000. The Lancet Global health 2: e80-89.

4. Shook, LM, and Ware, RE (2018). Sickle cell screening in Europe: the time has come. British journal of haematology 183: 534-535.

5. Flint, J, Harding, RM, Boyce, AJ, and Clegg, JB (1998). The population genetics of the haemoglobinopathies. Bailliere's clinical haematology 11: 1-51.

6. Finch, CA, and Sturgeon, P (1957). Erythrokinetics in Cooley's anemia. Blood 12: 64-73.

7. Camaschella, C, and Nai, A (2016). Ineffective erythropoiesis and regulation of iron status in iron loading anaemias. British journal of haematology 172: 512-523.

8. Taher, AT, and Saliba, AN (2017). Iron overload in thalassemia: different organs at different rates. Hematology American Society of Hematology Education Program 2017: 265-271.

9. Aydinok, Y, Porter, JB, Piga, A, Elalfy, M, ElBeshlawy, A, Kilinc, Y, et al. (2015). Prevalence 
and distribution of iron overload in patients with transfusion-dependent anemias differs across geographic regions: results from the CORDELIA study. European journal of haematology 95: 244-253.

10. Kremastinos, DT, Farmakis, D, Aessopos, A, Hahalis, G, Hamodraka, E, Tsiapras, D, et al. (2010). Beta-thalassemia cardiomyopathy: history, present considerations, and future perspectives. Circulation Heart failure 3: 451458.

11. Modell, B, Khan, M, Darlison, M, Westwood, MA, Ingram, D, and Pennell, DJ (2008). Improved survival of thalassaemia major in the UK and relation to $\mathrm{T} 2 *$ cardiovascular magnetic resonance. Journal of cardiovascular magnetic resonance : official journal of the Society for Cardiovascular Magnetic Resonance 10: 42.

12. Voskaridou, E, Ladis, V, Kattamis, A, Hassapopoulou, E, Economou, M, Kourakli, A, et al. (2012). A national registry of haemoglobinopathies in Greece: deducted demographics, trends in mortality and affected births. Annals of hematology 91: 1451-1458.

13. Marsella, M, and Ricchi, P (2019). Thalassemia and hepatocellular carcinoma: links and risks. Journal of blood medicine 10: 323-334.

14. Pinto, VM, Poggi, M, Russo, R, Giusti, A, and Forni, GL (2019). Management of the aging beta-thalassemia transfusion-dependent population - The Italian experience. Blood reviews 38: 100594.

15. Eaton, WA, and Hofrichter, J (1987). Hemoglobin $S$ gelation and sickle cell disease. Blood 70: 1245-1266.

16. Kato, GJ, Steinberg, MH, and Gladwin, MT (2017). Intravascular hemolysis and the pathophysiology of sickle cell disease. The Journal of clinical investigation 127: 750-760.

17. Sundd, P, Gladwin, MT, and Novelli, EM (2019). Pathophysiology of Sickle Cell Disease. Annual review of pathology 14: 263-292.

18. Thein, SL (2011). Genetic modifiers of sickle cell disease. Hemoglobin 35: 589-606.

19. Day, ME, Rodeghier, $M$, and DeBaun, MR (2018). Children with HbSbeta(0) thalassemia have higher hemoglobin levels and lower incidence rate of acute chest syndrome compared to children with HbSS. Pediatric blood \& cancer 65: e27352.

20. Gluckman, E, Cappelli, B, Bernaudin, F, Labopin, M, Volt, F, Carreras, J, et al. (2017). Sickle cell disease: an international survey of results of HLA-identical sibling hematopoietic stem cell transplantation. Blood 129: 1548-1556.

21. Angelucci, E (2010). Hematopoietic stem cell transplantation in thalassemia. Hematology American Society of Hematology Education Program 2010: 456-462.

22. Bhatia, M, Kolva, E, Cimini, L, Jin, Z, Satwani, P, Savone, M, et al. (2015). Health-related quality of life after allogeneic hematopoietic stem cell transplantation for sickle cell disease. Biology of blood and marrow transplantation : journal of the American Society for Blood and Marrow Transplantation 21: 666-672.

23. La Nasa, G, Caocci, G, Efficace, F, Dessi, C, Vacca, A, Piras, E, et al. (2013). Long-term healthrelated quality of life evaluated more than 20 years after hematopoietic stem cell transplantation for thalassemia. Blood 122: 2262-2270.

24. Locatelli, F, Merli, P, and Strocchio, L (2016). Transplantation for thalassemia major: alternative donors. Curr Opin Hematol 23: 515523.

25. Shenoy, S, Eapen, M, Panepinto, JA, Logan, BR, $\mathrm{Wu}, \mathrm{J}$, Abraham, A, et al. (2016). A trial of unrelated donor marrow transplantation for children with severe sickle cell disease. Blood 128: 2561-2567.

26. Platt, OS, Brambilla, DJ, Rosse, WF, Milner, PF, Castro, O, Steinberg, MH, et al. (1994). Mortality in sickle cell disease. Life expectancy and risk factors for early death. The New England journal of medicine 330: 1639-1644.

27. Sunshine, HR, Hofrichter, J, and Eaton, WA (1979). Gelation of sickle cell hemoglobin in mixtures with normal adult and fetal hemoglobins. Journal of molecular biology 133: 435-467.

28. Poillon, WN, Kim, BC, Rodgers, GP, Noguchi, CT, and Schechter, AN (1993). Sparing effect of hemoglobin $F$ and hemoglobin $A 2$ on the polymerization of hemoglobin $\mathrm{S}$ at physiologic ligand saturations. Proceedings of the National Academy of Sciences of the United States of America 90: 5039-5043.

29. Adachi, K, Konitzer, P, and Surrey, S (1994). Role of gamma $87 \mathrm{Gln}$ in the inhibition of hemoglobin $\mathrm{S}$ polymerization by hemoglobin $\mathrm{F}$. The Journal of biological chemistry 269: 9562-9567.

30. Nagel, RL, Bookchin, RM, Johnson, J, Labie, D, Wajcman, H, Isaac-Sodeye, WA, et al. (1979). 
Structural bases of the inhibitory effects of hemoglobin $\mathrm{F}$ and hemoglobin $\mathrm{A} 2$ on the polymerization of hemoglobin S. Proceedings of the National Academy of Sciences of the United States of America 76: 670-672.

31. Reddy, LR, Reddy, KS, Surrey, S, and Adachi, K (1997). Role of beta87 Thr in the beta6 Val acceptor site during deoxy $\mathrm{Hb} \mathrm{S}$ polymerization. Biochemistry 36: 15992-15998.

32. Pawliuk, R, Westerman, KA, Fabry, ME, Payen, $\mathrm{E}$, Tighe, R, Bouhassira, EE, et al. (2001). Correction of sickle cell disease in transgenic mouse models by gene therapy. Science 294: 2368-2371.

33. Chakalova, L, Osborne, CS, Dai, YF, Goyenechea, B, Metaxotou-Mavromati, A, Kattamis, A, et al. (2005). The Corfu deltabeta thalassemia deletion disrupts gamma-globin gene silencing and reveals post-transcriptional regulation of HbF expression. Blood 105: 2154-2160.

34. Russell, JE (2007). A post-transcriptional process contributes to efficient gamma-globin gene silencing in definitive erythroid cells. European journal of haematology 79: 516-525.

35. Kutlar, F, Gonzalez-Redondo, JM, Kutlar, A, Gurgey, A, Altay, C, Efremov, GD, et al. (1989). The levels of zeta, gamma, and delta chains in patients with $\mathrm{Hb} \mathrm{H}$ disease. Human genetics 82: 179-186.

36. Martinez, G, and Menendez, R (1983). Differences in affinity of beta and delta hemoglobin chains for alpha chains. A possible explanation for the variation in the percentages of hemoglobin $A 2$ in thalassemia and other disorders. Biochimica et biophysica acta 743: 256-259.

37. McCune, SL, Reilly, MP, Chomo, MJ, Asakura, T, and Townes, TM (1994). Recombinant human hemoglobins designed for gene therapy of sickle cell disease. Proceedings of the National Academy of Sciences of the United States of America 91: 9852-9856.

38. Bunn, HF, and McDonald, MJ (1983). Electrostatic interactions in the assembly of haemoglobin. Nature 306: 498-500.

39. Levasseur, DN, Ryan, TM, Reilly, MP, McCune, SL, Asakura, T, and Townes, TM (2004). A recombinant human hemoglobin with antisickling properties greater than fetal hemoglobin. The Journal of biological chemistry 279: 27518-27524.
40. Forrester, WC, Novak, U, Gelinas, R, and Groudine, M (1989). Molecular analysis of the human beta-globin locus activation region. Proceedings of the National Academy of Sciences of the United States of America 86: 5439-5443.

41. Talbot, $D$, Collis, $P$, Antoniou, $M$, Vidal, $M$, Grosveld, F, and Greaves, DR (1989). A dominant control region from the human betaglobin locus conferring integration siteindependent gene expression. Nature 338: 352355.

42. Gelinas, R, Frazier, A, and Harris, E (1992). A normal level of beta-globin expression in erythroid cells after retroviral cells transfer. Bone marrow transplantation 9 Suppl 1: 154157.

43. Novak, U, Harris, EA, Forrester, W, Groudine, M, and Gelinas, R (1990). High-level beta-globin expression after retroviral transfer of locus activation region-containing human beta-globin gene derivatives into murine erythroleukemia cells. Proceedings of the National Academy of Sciences of the United States of America 87: 3386-3390.

44. Rivella, S, and Sadelain, M (1998). Genetic treatment of severe hemoglobinopathies: the combat against transgene variegation and transgene silencing. Seminars in hematology 35: 112-125.

45. Plavec, I, Papayannopoulou, T, Maury, C, and Meyer, F (1993). A human beta-globin gene fused to the human beta-globin locus control region is expressed at high levels in erythroid cells of mice engrafted with retrovirustransduced hematopoietic stem cells. Blood 81: 1384-1392.

46. Leboulch, P, Huang, GM, Humphries, RK, Oh, YH, Eaves, CJ, Tuan, DY, et al. (1994). Mutagenesis of retroviral vectors transducing human betaglobin gene and beta-globin locus control region derivatives results in stable transmission of an active transcriptional structure. The EMBO journal 13: 3065-3076.

47. Sadelain, $\mathrm{M}$, Wang, $\mathrm{CH}$, Antoniou, $\mathrm{M}$, Grosveld, $F$, and Mulligan, RC (1995). Generation of a hightiter retroviral vector capable of expressing high levels of the human beta-globin gene. Proceedings of the National Academy of Sciences of the United States of America 92: 6728-6732. 
48. Raftopoulos, H, Ward, M, Leboulch, P, and Bank, A (1997). Long-term transfer and expression of the human beta-globin gene in a mouse transplant model. Blood 90: 3414-3422.

49. May, C, Rivella, S, Callegari, J, Heller, G, Gaensler, KM, Luzzatto, L, et al. (2000). Therapeutic haemoglobin synthesis in betathalassaemic mice expressing lentivirusencoded human beta-globin. Nature 406: 82-86.

50. Naldini, L, Blomer, U, Gallay, P, Ory, D, Mulligan, $\mathrm{R}$, Gage, $\mathrm{FH}$, et al. (1996). In vivo gene delivery and stable transduction of nondividing cells by a lentiviral vector. Science 272: 263-267.

51. Nakamura-Ishizu, A, Takizawa, H, and Suda, $T$ (2014). The analysis, roles and regulation of quiescence in hematopoietic stem cells. Development 141: 4656-4666.

52. Imren, S, Payen, E, Westerman, KA, Pawliuk, R, Fabry, ME, Eaves, CJ, et al. (2002). Permanent and panerythroid correction of murine beta thalassemia by multiple lentiviral integration in hematopoietic stem cells. Proceedings of the National Academy of Sciences of the United States of America 99: 14380-14385.

53. May, C, Rivella, S, Chadburn, A, and Sadelain, M (2002). Successful treatment of murine betathalassemia intermedia by transfer of the human beta-globin gene. Blood 99: 1902-1908.

54. Rouyer-Fessard, P, Leroy-Viard, K, Domenget, C, Mrad, A, and Beuzard, Y (1990). Mouse beta thalassemia, a model for the membrane defects of erythrocytes in the human disease. The Journal of biological chemistry 265: 2024720251.

55. Yang, B, Kirby, S, Lewis, J, Detloff, PJ, Maeda, N, and Smithies, O (1995). A mouse model for beta 0 -thalassemia. Proceedings of the National Academy of Sciences of the United States of America 92: 11608-11612.

56. Zennou, V, Petit, C, Guetard, D, Nerhbass, U, Montagnier, L, and Charneau, P (2000). HIV-1 genome nuclear import is mediated by a central DNA flap. Cell 101: 173-185.

57. Hanawa, H, Hargrove, PW, Kepes, S, Srivastava, DK, Nienhuis, AW, and Persons, DA (2004). Extended beta-globin locus control region elements promote consistent therapeutic expression of a gamma-globin lentiviral vector in murine beta-thalassemia. Blood 104: 22812290.

58. Puthenveetil, G, Scholes, J, Carbonell, D, Qureshi, N, Xia, P, Zeng, L, et al. (2004).
Successful correction of the human betathalassemia major phenotype using a lentiviral vector. Blood 104: 3445-3453.

59. Miccio, A, Cesari, R, Lotti, F, Rossi, C, Sanvito, F, Ponzoni, $M$, et al. (2008). In vivo selection of genetically modified erythroblastic progenitors leads to long-term correction of betathalassemia. Proceedings of the National Academy of Sciences of the United States of America 105: 10547-10552.

60. Trudel, M, De Paepe, ME, Chretien, N, Saadane, $\mathrm{N}$, Jacmain, J, Sorette, M, et al. (1994). Sickle cell disease of transgenic SAD mice. Blood 84: 31893197.

61. Paszty, C, Brion, CM, Manci, E, Witkowska, HE, Stevens, ME, Mohandas, N, et al. (1997). Transgenic knockout mice with exclusively human sickle hemoglobin and sickle cell disease. Science 278: 876-878.

62. Pestina, TI, Hargrove, PW, Jay, D, Gray, JT, Boyd, KM, and Persons, DA (2009). Correction of murine sickle cell disease using gamma-globin lentiviral vectors to mediate high-level expression of fetal hemoglobin. Molecular therapy : the journal of the American Society of Gene Therapy 17: 245-252.

63. Ryan, TM, Ciavatta, DJ, and Townes, TM (1997). Knockout-transgenic mouse model of sickle cell disease. Science 278: 873-876.

64. Levasseur, DN, Ryan, TM, Pawlik, KM, and Townes, TM (2003). Correction of a mouse model of sickle cell disease: lentiviral/antisickling beta-globin gene transduction of unmobilized, purified hematopoietic stem cells. Blood 102: 43124319.

65. Akinsheye, I, Alsultan, A, Solovieff, N, Ngo, D, Baldwin, CT, Sebastiani, P, et al. (2011). Fetal hemoglobin in sickle cell anemia. Blood 118: 1927.

66. Rivella, S, May, C, Chadburn, A, Riviere, I, and Sadelain, M (2003). A novel murine model of Cooley anemia and its rescue by lentiviralmediated human beta-globin gene transfer. Blood 101: 2932-2939.

67. Li, CL, and Emery, DW (2008). The cHS4 chromatin insulator reduces gammaretroviral vector silencing by epigenetic modifications of integrated provirus. Gene therapy 15: 49-53.

68. Arumugam, PI, Scholes, J, Perelman, N, Xia, P, Yee, JK, and Malik, P (2007). Improved human beta-globin expression from self-inactivating 
lentiviral vectors carrying the chicken hypersensitive site-4 (cHS4) insulator element. Molecular therapy : the journal of the American Society of Gene Therapy 15: 1863-1871.

69. Urbinati, F, Arumugam, P, Higashimoto, T, Perumbeti, A, Mitts, K, Xia, P, et al. (2009). Mechanism of reduction in titers from lentivirus vectors carrying large inserts in the 3'LTR. Molecular therapy : the journal of the American Society of Gene Therapy 17: 1527-1536.

70. Ronen, K, Negre, O, Roth, S, Colomb, C, Malani, N, Denaro, M, et al. (2011). Distribution of lentiviral vector integration sites in mice following therapeutic gene transfer to treat beta-thalassemia. Molecular therapy : the journal of the American Society of Gene Therapy 19: $1273-1286$.

71. Aker, M, Tubb, J, Groth, AC, Bukovsky, AA, Bell, AC, Felsenfeld, G, et al. (2007). Extended core sequences from the cHS4 insulator are necessary for protecting retroviral vectors from silencing position effects. Human gene therapy 18: 333-343.

72. Arumugam, PI, Urbinati, F, Velu, CS, Higashimoto, T, Grimes, HL, and Malik, P (2009). The 3' region of the chicken hypersensitive site4 insulator has properties similar to its core and is required for full insulator activity. PloS one 4: e6995.

73. Uchida, N, Washington, KN, Lap, CJ, Hsieh, MM, and Tisdale, JF (2011). Chicken HS4 insulators have minimal barrier function among progeny of human hematopoietic cells transduced with an HIV1-based lentiviral vector. Molecular therapy : the journal of the American Society of Gene Therapy 19: 133-139.

74. Negre, O, Bartholomae, C, Beuzard, Y, Cavazzana, M, Christiansen, L, Courne, C, et al. (2015). Preclinical evaluation of efficacy and safety of an improved lentiviral vector for the treatment of beta-thalassemia and sickle cell disease. Current gene therapy 15: 64-81.

75. Ramezani, A, Hawley, TS, and Hawley, RG (2003). Performance- and safety-enhanced lentiviral vectors containing the human interferon-beta scaffold attachment region and the chicken beta-globin insulator. Blood 101: 4717-4724.

76. Hanawa, H, Yamamoto, M, Zhao, H, Shimada, T, and Persons, DA (2009). Optimized lentiviral vector design improves titer and transgene expression of vectors containing the chicken beta-globin locus HS4 insulator element. Molecular therapy : the journal of the American Society of Gene Therapy 17: 667-674.

77. Montini, E, Cesana, D, Schmidt, M, Sanvito, F, Bartholomae, CC, Ranzani, M, et al. (2009). The genotoxic potential of retroviral vectors is strongly modulated by vector design and integration site selection in a mouse model of HSC gene therapy. The Journal of clinical investigation 119: 964-975.

78. Ranzani, M, Cesana, D, Bartholomae, CC, Sanvito, F, Pala, M, Benedicenti, F, et al. (2013). Lentiviral vector-based insertional mutagenesis identifies genes associated with liver cancer. Nature methods 10: 155-161.

79. Maruggi, G, Porcellini, S, Facchini, G, Perna, SK, Cattoglio, C, Sartori, D, et al. (2009). Transcriptional enhancers induce insertional gene deregulation independently from the vector type and design. Molecular therapy : the journal of the American Society of Gene Therapy 17: 851-856.

80. Arumugam, PI, Higashimoto, T, Urbinati, F, Modlich, U, Nestheide, S, Xia, P, et al. (2009). Genotoxic potential of lineage-specific lentivirus vectors carrying the beta-globin locus control region. Molecular therapy : the journal of the American Society of Gene Therapy 17: 1929-1937.

81. Bushman, F, Lewinski, M, Ciuffi, A, Barr, S, Leipzig, J, Hannenhalli, S, et al. (2005). Genomewide analysis of retroviral DNA integration. Nature reviews Microbiology 3: 848-858.

82. Zychlinski, D, Schambach, A, Modlich, U, Maetzig, T, Meyer, J, Grassman, E, et al. (2008). Physiological promoters reduce the genotoxic risk of integrating gene vectors. Molecular therapy : the journal of the American Society of Gene Therapy 16: 718-725.

83. Chang, $A H$, and Sadelain, M (2007). The genetic engineering of hematopoietic stem cells: the rise of lentiviral vectors, the conundrum of the Itr, and the promise of lineage-restricted vectors. Molecular therapy : the journal of the American Society of Gene Therapy 15: 445-456.

84. Modlich, U, Navarro, S, Zychlinski, D, Maetzig, T, Knoess, S, Brugman, $\mathrm{MH}$, et al. (2009). Insertional transformation of hematopoietic cells by self-inactivating lentiviral and gammaretroviral vectors. Molecular therapy : the journal of the American Society of Gene Therapy 17: 1919-1928. 
85. Grosveld, F, van Assendelft, GB, Greaves, DR, and Kollias, G (1987). Position-independent, high-level expression of the human beta-globin gene in transgenic mice. Cell 51: 975-985.

86. Forrester, WC, Epner, E, Driscoll, MC, Enver, T, Brice, M, Papayannopoulou, T, et al. (1990). A deletion of the human beta-globin locus activation region causes a major alteration in chromatin structure and replication across the entire beta-globin locus. Genes \& development 4: 1637-1649.

87. Jimenez, G, Griffiths, SD, Ford, AM, Greaves, MF, and Enver, $T$ (1992). Activation of the betaglobin locus control region precedes commitment to the erythroid lineage. Proceedings of the National Academy of Sciences of the United States of America 89: 10618-10622.

88. Papayannopoulou, T, Priestley, GV, Rohde, A, Peterson, KR, and Nakamoto, B (2000). Hemopoietic lineage commitment decisions: in vivo evidence from a transgenic mouse model harboring micro LCR-betapro-LacZ as a transgene. Blood 95: 1274-1282.

89. Hargrove, PW, Kepes, S, Hanawa, H, Obenauer, JC, Pei, D, Cheng, C, et al. (2008). Globin lentiviral vector insertions can perturb the expression of endogenous genes in betathalassemic hematopoietic cells. Molecular therapy : the journal of the American Society of Gene Therapy 16: 525-533.

90. Bell, AC, West, AG, and Felsenfeld, G (1999). The protein CTCF is required for the enhancer blocking activity of vertebrate insulators. Cell 98: 387-396.

91. Recillas-Targa, F, Pikaart, MJ, Burgess-Beusse, B, Bell, AC, Litt, MD, West, AG, et al. (2002). Position-effect protection and enhancer blocking by the chicken beta-globin insulator are separable activities. Proceedings of the National Academy of Sciences of the United States of America 99: 6883-6888.

92. Ramezani, A, Hawley, TS, and Hawley, RG (2008). Combinatorial incorporation of enhancer-blocking components of the chicken beta-globin 5'HS4 and human T-cell receptor alpha/delta BEAD-1 insulators in selfinactivating retroviral vectors reduces their genotoxic potential. Stem cells 26: 3257-3266.

93. Romero, Z, Urbinati, F, Geiger, S, Cooper, AR, Wherley, J, Kaufman, ML, et al. (2013). betaglobin gene transfer to human bone marrow for sickle cell disease. The Journal of clinical investigation.

94. Urbinati, F, Campo Fernandez, B, Masiuk, KE, Poletti, V, Hollis, RP, Koziol, C, et al. (2018). Gene Therapy for Sickle Cell Disease: A Lentiviral Vector Comparison Study. Human gene therapy 29: 1153-1166.

95. Gaszner, M, and Felsenfeld, G (2006). Insulators: exploiting transcriptional and epigenetic mechanisms. Nature reviews Genetics 7: 703-713.

96. Desprat, R, and Bouhassira, EE (2009). Gene specificity of suppression of transgenemediated insertional transcriptional activation by the chicken HS4 insulator. PloS one 4: e5956.

97. Moiani, A, Paleari, Y, Sartori, D, Mezzadra, R, Miccio, A, Cattoglio, C, et al. (2012). Lentiviral vector integration in the human genome induces alternative splicing and generates aberrant transcripts. The Journal of clinical investigation 122: 1653-1666.

98. Cavazzana-Calvo, M, Payen, E, Negre, O, Wang, G, Hehir, K, Fusil, F, et al. (2010). Transfusion independence and HMGA2 activation after gene therapy of human beta-thalassaemia. Nature 467: 318-322.

99. Morgan, RA, Unti, MJ, Aleshe, B, Brown, D, Osborne, KS, Koziol, C, et al. (2020). Improved Titer and Gene Transfer by Lentiviral Vectors Using Novel, Small beta-Globin Locus Control Region Elements. Molecular therapy : the journal of the American Society of Gene Therapy 28: 328-340.

100. Breda, L, Casu, C, Gardenghi, S, Bianchi, N, Cartegni, L, Narla, M, et al. (2012). Therapeutic hemoglobin levels after gene transfer in betathalassemia mice and in hematopoietic cells of beta-thalassemia and sickle cells disease patients. PloS one 7: e32345.

101. Urbinati, F, Hargrove, PW, Geiger, S, Romero, Z, Wherley, J, Kaufman, ML, et al. (2015). Potentially therapeutic levels of anti-sickling globin gene expression following lentivirusmediated gene transfer in sickle cell disease bone marrow CD34+ cells. Experimental hematology 43: 346-351.

102. Urbinati, F, Wherley, J, Geiger, S, Fernandez, BC, Kaufman, ML, Cooper, A, et al. (2017). Preclinical studies for a phase 1 clinical trial of autologous hematopoietic stem cell gene therapy for sickle cell disease. Cytotherapy 19: 1096-1112. 
103. Navas, PA, Peterson, KR, Li, Q, McArthur, $M$, and Stamatoyannopoulos, G (2001). The 5'HS4 core element of the human beta-globin locus control region is required for high-level globin gene expression in definitive but not in primitive erythropoiesis. Journal of molecular biology 312: 17-26.

104. Perumbeti, A, Higashimoto, T, Urbinati, F, Franco, R, Meiselman, HJ, Witte, D, et al. (2009). A novel human gamma-globin gene vector for genetic correction of sickle cell anemia in a humanized sickle mouse model: critical determinants for successful correction. Blood 114: 1174-1185.

105. Roselli, EA, Mezzadra, R, Frittoli, MC, Maruggi, G, Biral, E, Mavilio, F, et al. (2010). Correction of beta-thalassemia major by gene transfer in haematopoietic progenitors of pediatric patients. EMBO molecular medicine 2: 315-328.

106. Boulad, F, Wang, X, Qu, J, Taylor, C, Ferro, L, Karponi, G, et al. (2014). Safe mobilization of CD34+ cells in adults with beta-thalassemia and validation of effective globin gene transfer for clinical investigation. Blood 123: 1483-1486.

107. Kiem, HP, Arumugam, PI, Burtner, CR, Fox, CF, Beard, BC, Dexheimer, P, et al. (2014). Pigtailed macaques as a model to study long-term safety of lentivirus vector-mediated gene therapy for hemoglobinopathies. Molecular therapy Methods \& clinical development 1: 14055.

108. Poletti, V, Urbinati, F, Charrier, S, Corre, G, Hollis, RP, Campo Fernandez, B, et al. (2018). Pre-clinical Development of a Lentiviral Vector Expressing the Anti-sickling betaAS3 Globin for Gene Therapy for Sickle Cell Disease. Molecular therapy Methods \& clinical development 11: 167-179.

109. Lettre, G, Sankaran, VG, Bezerra, MA, Araujo, AS, Uda, M, Sanna, S, et al. (2008). DNA polymorphisms at the BCL11A, HBS1L-MYB, and beta-globin loci associate with fetal hemoglobin levels and pain crises in sickle cell disease. Proceedings of the National Academy of Sciences of the United States of America 105: 11869-11874.

110. Uda, M, Galanello, R, Sanna, S, Lettre, G, Sankaran, VG, Chen, W, et al. (2008). Genomewide association study shows BCL11A associated with persistent fetal hemoglobin and amelioration of the phenotype of betathalassemia. Proceedings of the National
Academy of Sciences of the United States of America 105: 1620-1625.

111. Sankaran, VG, Menne, TF, Xu, J, Akie, TE, Lettre, G, Van Handel, B, et al. (2008). Human fetal hemoglobin expression is regulated by the developmental stage-specific repressor BCL11A. Science 322: 1839-1842.

112. Menzel, S, Garner, C, Gut, I, Matsuda, F, Yamaguchi, M, Heath, S, et al. (2007). A QTL influencing $F$ cell production maps to a gene encoding a zinc-finger protein on chromosome 2p15. Nat Genet 39: 1197-1199.

113. Thein, SL, Menzel, S, Peng, X, Best, S, Jiang, J, Close, J, et al. (2007). Intergenic variants of HBS1L-MYB are responsible for a major quantitative trait locus on chromosome $6 q 23$ influencing fetal hemoglobin levels in adults. Proceedings of the National Academy of Sciences of the United States of America 104: 11346-11351.

114. Liu, P, Keller, JR, Ortiz, M, Tessarollo, L, Rachel, RA, Nakamura, T, et al. (2003). Bcl11a is essential for normal lymphoid development. Nat Immunol 4: 525-532.

115. Tsang, JC, Yu, Y, Burke, S, Buettner, F, Wang, C, Kolodziejczyk, AA, et al. (2015). Single-cell transcriptomic reconstruction reveals cell cycle and multi-lineage differentiation defects in Bcl11a-deficient hematopoietic stem cells. Genome Biol 16: 178.

116. Wilber, A, Hargrove, PW, Kim, YS, Riberdy, JM, Sankaran, VG, Papanikolaou, E, et al. (2011). Therapeutic levels of fetal hemoglobin in erythroid progeny of beta-thalassemic CD34+ cells after lentiviral vector-mediated gene transfer. Blood 117: 2817-2826.

117. Brendel, C, Guda, S, Renella, R, Bauer, DE, Canver, MC, Kim, YJ, et al. (2016). Lineagespecific BCL11A knockdown circumvents toxicities and reverses sickle phenotype. The Journal of clinical investigation 126: 3868-3878.

118. Guda, S, Brendel, C, Renella, R, Du, P, Bauer, DE, Canver, MC, et al. (2015). miRNA-embedded shRNAs for Lineage-specific BCL11A Knockdown and Hemoglobin F Induction. Molecular therapy : the journal of the American Society of Gene Therapy 23: 1465-1474.

119. Brendel, C, Negre, O, Rothe, M, Guda, S, Parsons, G, Harris, C, et al. (2020). Preclinical Evaluation of a Novel Lentiviral Vector Driving Lineage-Specific BCL11A Knockdown for Sickle 
Cell Gene Therapy. Molecular therapy Methods \& clinical development 17: 589-600.

120. Esrick, EB, Brendel, C, Manis, JP, Armant, MA, Negre, H, Dansereau, C, et al. (2018). Flipping the switch: initial results of genetic targeting of the Fetal to adult globin switch in sickle cell patients. Blood 132: 1023-1023.

121. Shrivastav, M, De Haro, LP, and Nickoloff, JA (2008). Regulation of DNA double-strand break repair pathway choice. Cell research 18: 134147.

122. Wattanapanitch, $M$, Damkham, N, Potirat, $P$, Trakarnsanga, K, Janan, M, Y, UP, et al. (2018). One-step genetic correction of hemoglobin $\mathrm{E} /$ beta-thalassemia patient-derived iPSCs by the CRISPR/Cas9 system. Stem cell research \& therapy 9: 46.

123. Xie, F, Ye, L, Chang, JC, Beyer, Al, Wang, J, Muench, MO, et al. (2014). Seamless gene correction of $\beta$-thalassemia mutations in patient-specific iPSCs using CRISPR/Cas9 and piggyBac. Genome Res 24: 1526-1533.

124. Ma, N, Liao, B, Zhang, H, Wang, L, Shan, Y, Xue, $Y$, et al. (2013). Transcription activator-like effector nuclease (TALEN)-mediated gene correction in integration-free $\beta$-thalassemia induced pluripotent stem cells. The Journal of biological chemistry 288: 34671-34679.

125. Sun, N, Liang, J, Abil, Z, and Zhao, H (2012). Optimized TAL effector nucleases (TALENs) for use in treatment of sickle cell disease. $\mathrm{Mol}$ Biosyst 8: 1255-1263.

126. Ramalingam, S, Annaluru, N, Kandavelou, K, and Chandrasegaran, S (2014). TALEN-mediated generation and genetic correction of diseasespecific human induced pluripotent stem cells. Current gene therapy 14: 461-472.

127. Huang, X, Wang, Y, Yan, W, Smith, C, Ye, Z, Wang, J, et al. (2015). Production of GeneCorrected Adult Beta Globin Protein in Human Erythrocytes Differentiated from Patient iPSCs After Genome Editing of the Sickle Point Mutation. Stem cells 33: 1470-1479.

128. Hoban, MD, Cost, GJ, Mendel, MC, Romero, Z, Kaufman, ML, Joglekar, AV, et al. (2015). Correction of the sickle cell disease mutation in human hematopoietic stem/progenitor cells. Blood 125: 2597-2604.

129. Zou, J, Mali, P, Huang, X, Dowey, SN, and Cheng, $L$ (2011). Site-specific gene correction of a point mutation in human iPS cells derived from an adult patient with sickle cell disease. Blood 118: 4599-4608.

130. Antony, JS, Latifi, N, Haque, A, Lamsfus-Calle, A, Daniel-Moreno, A, Graeter, S, et al. (2018). Gene correction of HBB mutations in CD34(+) hematopoietic stem cells using Cas9 mRNA and ssODN donors. Mol Cell Pediatr 5: 9.

131. Dever, DP, Bak, RO, Reinisch, A, Camarena, J, Washington, G, Nicolas, CE, et al. (2016). CRISPR/Cas9 $\beta$-globin gene targeting in human haematopoietic stem cells. Nature 539: 384389.

132. Romero, Z, Lomova, A, Said, S, Miggelbrink, A, Kuo, CY, Campo-Fernandez, B, et al. (2019). Editing the Sickle Cell Disease Mutation in Human Hematopoietic Stem Cells: Comparison of Endonucleases and Homologous Donor Templates. Molecular therapy : the journal of the American Society of Gene Therapy 27: 13891406.

133. Pattabhi, S, Lotti, SN, Berger, MP, Singh, S, Lux, $\mathrm{CT}$, Jacoby, K, et al. (2019). In Vivo Outcome of Homology-Directed Repair at the HBB Gene in HSC Using Alternative Donor Template Delivery Methods. Molecular therapy Nucleic acids 17: 277-288.

134. Genovese, P, Schiroli, G, Escobar, G, Di Tomaso, T, Firrito, C, Calabria, A, et al. (2014). Targeted genome editing in human repopulating haematopoietic stem cells. Nature 510: 235240.

135. Fessas, P, and Stamatoyannopoulos, G (1964). HEREDITARY PERSISTENCE OF FETAL HEMOGLOBIN IN GREECE. A STUDY AND A COMPARISON. Blood 24: 223-240.

136. Collins, FS, Metherall, JE, Yamakawa, M, Pan, J, Weissman, SM, and Forget, BG (1985). A point mutation in the $A$ gamma-globin gene promoter in Greek hereditary persistence of fetal haemoglobin. Nature 313: 325-326.

137. Oner, R, Kutlar, F, Gu, LH, and Huisman, TH (1991). The Georgia type of nondeletional hereditary persistence of fetal hemoglobin has a C---T mutation at nucleotide-114 of the A gamma-globin gene. Blood 77: 1124-1125.

138. Fucharoen, S, Shimizu, $K$, and Fukumaki, $Y$ (1990). A novel C-T transition within the distal CCAAT motif of the $\mathrm{G}$ gamma-globin gene in the Japanese HPFH: implication of factor binding in elevated fetal globin expression. Nucleic acids research 18: 5245-5253. 
139. Gilman, JG, Mishima, N, Wen, XJ, Stoming, TA, Lobel, J, and Huisman, TH (1988). Distal CCAAT box deletion in the A gamma globin gene of two black adolescents with elevated fetal A gamma globin. Nucleic acids research 16: 10635-10642.

140. Zertal-Zidani, S, Merghoub, T, Ducrocq, R, Gerard, N, Satta, D, and Krishnamoorthy, R (1999). A novel C-->A transversion within the distal CCAAT motif of the Ggamma-globin gene in the Algerian Ggammabeta+-hereditary persistence of fetal hemoglobin. Hemoglobin 23: 159-169.

141. Giglioni, B, Casini, C, Mantovani, R, Merli, S, Comi, $\mathrm{P}$, Ottolenghi, S, et al. (1984). A molecular study of a family with Greek hereditary persistence of fetal hemoglobin and betathalassemia. The EMBO journal 3: 2641-2645.

142. Tasiopoulou, M, Boussiou, M, Sinopoulou, K, Moraitis, G, Loutradi-Anagnostou, A, and Karababa, P (2008). G gamma-196 C-->T, A gamma-201 C-->T: two novel mutations in the promoter region of the gamma-globin genes associated with nondeletional hereditary persistence of fetal hemoglobin in Greece. Blood cells, molecules \& diseases 40: 320-322.

143. Amato, A, Cappabianca, MP, Perri, M, Zaghis, I, Grisanti, P, Ponzini, D, et al. (2014). Interpreting elevated fetal hemoglobin in pathology and health at the basic laboratory level: new and known $\gamma$ - gene mutations associated with hereditary persistence of fetal hemoglobin. Int J Lab Hematol 36: 13-19.

144. Collins, FS, Stoeckert, CJ, Jr., Serjeant, GR, Forget, BG, and Weissman, SM (1984). G gamma beta+ hereditary persistence of fetal hemoglobin: cosmid cloning and identification of a specific mutation 5 ' to the $\mathrm{G}$ gamma gene. Proceedings of the National Academy of Sciences of the United States of America 81: 4894-4898.

145. Hattori, Y, Kutlar, F, Kutlar, A, McKie, VC, and Huisman, TH (1986). Haplotypes of beta $S$ chromosomes among patients with sickle cell anemia from Georgia. Hemoglobin 10: 623-642.

146. Motum, PI, Deng, ZM, Huong, L, and Trent, RJ (1994). The Australian type of nondeletional $G$ gamma-HPFH has a C-->G substitution at nucleotide -114 of the $\mathrm{G}$ gamma gene. British journal of haematology 86: 219-221.

147. Gilman, JG, Mishima, N, Wen, XJ, Kutlar, F, and Huisman, TH (1988). Upstream promoter mutation associated with a modest elevation of fetal hemoglobin expression in human adults. Blood 72: 78-81.

148. Wienert, B, Funnell, AP, Norton, LJ, Pearson, RC, Wilkinson-White, LE, Lester, K, et al. (2015). Editing the genome to introduce a beneficial naturally occurring mutation associated with increased fetal globin. Nature communications 6: 7085.

149. Martyn, GE, Wienert, B, Yang, L, Shah, M, Norton, L, Burdach, J, et al. (2018). Natural regulatory mutations elevate the fetal globin gene via disruption of BCL11A or ZBTB7A binding. Nat Genet 50: 498-503.

150. Martyn, GE, Wienert, B, Kurita, R, Nakamura, $Y$, Quinlan, KGR, and Crossley, M (2019). A natural regulatory mutation in the proximal promoter elevates fetal globin expression by creating a de novo GATA1 site. Blood 133: 852-856.

151. Branzei, D, and Foiani, M (2008). Regulation of DNA repair throughout the cell cycle. Nature reviews Molecular cell biology 9: 297-308.

152. Lomova, A, Clark, DN, Campo-Fernandez, B, Flores-Bjurstrom, C, Kaufman, ML, Fitz-Gibbon, $S$, et al. (2019). Improving Gene Editing Outcomes in Human Hematopoietic Stem and Progenitor Cells by Temporal Control of DNA Repair. Stem cells 37: 284-294.

153. Lux, CT, Pattabhi, S, Berger, $M$, Nourigat, $C$, Flowers, DA, Negre, O, et al. (2019). TALENMediated Gene Editing of HBG in Human Hematopoietic Stem Cells Leads to Therapeutic Fetal Hemoglobin Induction. Molecular therapy Methods \& clinical development 12: 175-183.

154. Traxler, EA, Yao, Y, Wang, YD, Woodard, KJ, Kurita, R, Nakamura, $Y$, et al. (2016). A genomeediting strategy to treat betahemoglobinopathies that recapitulates a mutation associated with a benign genetic condition. Nature medicine 22: 987-990.

155. Ye, L, Wang, J, Tan, Y, Beyer, Al, Xie, F, Muench, MO, et al. (2016). Genome editing using CRISPRCas9 to create the HPFH genotype in HSPCs: An approach for treating sickle cell disease and beta-thalassemia. Proceedings of the National Academy of Sciences of the United States of America 113: 10661-10665.

156. Lattanzi, A, Meneghini, V, Pavani, G, Amor, F, Ramadier, S, Felix, T, et al. (2019). Optimization of CRISPR/Cas9 Delivery to Human Hematopoietic Stem and Progenitor Cells for Therapeutic Genomic Rearrangements. 
Molecular therapy : the journal of the American Society of Gene Therapy 27: 137-150.

157. Lamsfus-Calle, A, Daniel-Moreno, A, Antony, JS, Epting, T, Heumos, L, Baskaran, P, et al. (2020). Comparative targeting analysis of KLF1, BCL11A, and HBG1/2 in CD34(+) HSPCs by CRISPR/Cas9 for the induction of fetal hemoglobin. Scientific reports 10: 10133.

158. Humbert, O, Radtke, S, Samuelson, C, Carrillo, RR, Perez, AM, Reddy, SS, et al. (2019). Therapeutically relevant engraftment of a CRISPR-Cas9-edited HSC-enriched population with $\mathrm{HbF}$ reactivation in nonhuman primates. Sci Transl Med 11.

159. Metais, JY, Doerfler, PA, Mayuranathan, T, Bauer, DE, Fowler, SC, Hsieh, MM, et al. (2019). Genome editing of HBG1 and HBG2 to induce fetal hemoglobin. Blood advances 3: 3379-3392.

160. Bauer, DE, Kamran, SC, Lessard, S, Xu, J, Fujiwara, Y, Lin, C, et al. (2013). An erythroid enhancer of BCL11A subject to genetic variation determines fetal hemoglobin level. Science 342: 253-257.

161. Canver, MC, Smith, EC, Sher, F, Pinello, L, Sanjana, NE, Shalem, O, et al. (2015). BCL11A enhancer dissection by Cas9-mediated in situ saturating mutagenesis. Nature 527: 192-197.

162. Wu, Y, Zeng, J, Roscoe, BP, Liu, P, Yao, Q, Lazzarotto, CR, et al. (2019). Highly efficient therapeutic gene editing of human hematopoietic stem cells. Nat Med 25: 776-783.

163. Boulad, F, Riviere, I, Wang, X, Bartido, S, Prockop, SE, Barone, R, et al. (2013). Fisrt US phase I clinical trial of globin gene trasfer for the treatment of beta-thalassemia major. Blood 122: 716.

164. Mansilla-Soto, J, Riviere, I, Boulad, F, and Sadelain, M (2016). Cell and Gene Therapy for the Beta-Thalassemias: Advances and Prospects. Human gene therapy 27: 295-304.

165. Negre, O, Eggimann, AV, Beuzard, Y, Ribeil, JA, Bourget, P, Borwornpinyo, S, et al. (2016). Gene Therapy of the beta-Hemoglobinopathies by Lentiviral Transfer of the beta(A(T87Q))-Globin Gene. Human gene therapy 27: 148-165.

166. Cavazzana, M, Bushman, FD, Miccio, A, AndreSchmutz, I, and Six, E (2019). Gene therapy targeting haematopoietic stem cells for inherited diseases: progress and challenges. Nature reviews Drug discovery 18: 447-462.

167. Ribeil, JA, Hacein-Bey-Abina, S, Payen, E, Magnani, A, Semeraro, M, Magrin, E, et al.
(2017). Gene Therapy in a Patient with Sickle Cell Disease. The New England journal of medicine 376: 848-855.

168. Thompson, AA, Walters, MC, Kwiatkowski, J, Rasko, JEJ, Ribeil, JA, Hongeng, S, et al. (2018). Gene Therapy in Patients with TransfusionDependent beta-Thalassemia. The New England journal of medicine 378: 1479-1493.

169. Marktel, S, Scaramuzza, S, Cicalese, MP, Giglio, F, Galimberti, S, Lidonnici, MR, et al. (2019). Intrabone hematopoietic stem cell gene therapy for adult and pediatric patients affected by transfusion-dependent ss-thalassemia. Nature medicine 25: 234-241.

170. Malik, P, Grimley, M, Quinn, CT, Shova, A, Courtney, L, Lutzko, C, et al. (2018). Gene therapy for sickle cell anemia using a modified gamma globin lentivirus vector and reduced intensity conditioning transplant shows promising correction of the disease phenotype. Blood 132(Suppl. 1): Abstract 1021.

171. Bueren, JA, Quintana-Bustamante, O, Almarza, E, Navarro, S, Rio, P, Segovia, JC, et al. (2020). Advances in the gene therapy of monogenic blood cell diseases. Clinical genetics 97: 89-102.

172. Esrick, E, Achebe, $M$, Armant, $M$, Bartolucci, $P$, Ciuculescu, MF, Daley, H, et al. (2019). Validation of BCL11A as therapeutic target in sickle cell disease: results from the adult cohort of a pilot/feasibility gene therapy trail inducing sustained expression of fetal hemoglobin using post-transcriptional gene silencing. Blood 134(Suppl. 2): Abstract LBA-5.

173. Holmes, MC, Reik, A, Rebar, EJ, Miller, JC, Zhou, $Y$, Zhang, L, et al. (2017). A potential therapy for beta-thalassemia (ST-400) and sickle cell disease (BIVV003). Blood 130(Suppl. 1): Abstract 2066.

174. You, L, Tong, R, Li, M, Liu, Y, Xue, J, and Lu, Y (2019). Advancements and Obstacles of CRISPRCas9 Technology in Translational Research. Molecular therapy Methods \& clinical development 13: 359-370.

175. Harrison, C (2019). First gene therapy for betathalassemia approved. Nature biotechnology 37: 1102-1103.

176. Takahashi, K, and Yamanaka, S (2006). Induction of pluripotent stem cells from mouse embryonic and adult fibroblast cultures by defined factors. Cell 126: 663-676.

177. Hanna, J, Wernig, M, Markoulaki, S, Sun, CW, Meissner, A, Cassady, JP, et al. (2007). 
Treatment of sickle cell anemia mouse model with iPS cells generated from autologous skin. Science 318: 1920-1923.

178. Sebastiano, V, Maeder, ML, Angstman, JF, Haddad, B, Khayter, C, Yeo, DT, et al. (2011). In situ genetic correction of the sickle cell anemia mutation in human induced pluripotent stem cells using engineered zinc finger nucleases. Stem cells 29: 1717-1726.

179. Sun, $N$, and Zhao, $H$ (2014). Seamless correction of the sickle cell disease mutation of the HBB gene in human induced pluripotent stem cells using TALENs. Biotechnology and bioengineering 111: 1048-1053.

180. Cai, L, Bai, H, Mahairaki, V, Gao, Y, He, C, Wen, $Y$, et al. (2018). A Universal Approach to Correct Various HBB Gene Mutations in Human Stem Cells for Gene Therapy of Beta-Thalassemia and Sickle Cell Disease. Stem cells translational medicine 7: 87-97.

181. Martin, RM, Ikeda, K, Cromer, MK, Uchida, N, Nishimura, T, Romano, R, et al. (2019). Highly Efficient and Marker-free Genome Editing of Human Pluripotent Stem Cells by CRISPR-Cas9 RNP and AAV6 Donor-Mediated Homologous Recombination. Cell stem cell 24: 821-828 e825.

182. Wang, Y, Zheng, CG, Jiang, Y, Zhang, J, Chen, J, Yao, C, et al. (2012). Genetic correction of betathalassemia patient-specific iPS cells and its use in improving hemoglobin production in irradiated SCID mice. Cell research 22: 637-648.

183. Papapetrou, EP, Lee, G, Malani, N, Setty, M, Riviere, I, Tirunagari, LM, et al. (2011). Genomic safe harbors permit high beta-globin transgene expression in thalassemia induced pluripotent stem cells. Nature biotechnology 29: 73-78.

184. Tubsuwan, A, Abed, S, Deichmann, A, Kardel, MD, Bartholoma, C, Cheung, A, et al. (2013). Parallel assessment of globin lentiviral transfer in induced pluripotent stem cells and adult hematopoietic stem cells derived from the same transplanted beta-thalassemia patient. Stem cells 31: 1785-1794.

185. Ma, N, Liao, B, Zhang, H, Wang, L, Shan, Y, Xue, $Y$, et al. (2013). Transcription activator-like effector nuclease (TALEN)-mediated gene correction in integration-free beta-thalassemia induced pluripotent stem cells. The Journal of biological chemistry 288: 34671-34679.

186. Ma, N, Shan, Y, Liao, B, Kong, G, Wang, C, Huang, $K$, et al. (2015). Factor-induced Reprogramming and Zinc Finger Nuclease-aided Gene Targeting
Cause Different Genome Instability in betaThalassemia Induced Pluripotent Stem Cells (iPSCs). The Journal of biological chemistry 290: 12079-12089.

187. Niu, X, He, W, Song, B, Ou, Z, Fan, D, Chen, Y, et al. (2016). Combining Single Strand Oligodeoxynucleotides and CRISPR/Cas9 to Correct Gene Mutations in beta-Thalassemiainduced Pluripotent Stem Cells. The Journal of biological chemistry 291: 16576-16585.

188. Ou, Z, Niu, X, He, W, Chen, Y, Song, B, Xian, Y, et al. (2016). The Combination of CRISPR/Cas9 and iPSC Technologies in the Gene Therapy of Human beta-thalassemia in Mice. Scientific reports 6: 32463.

189. Song, B, Fan, Y, He, W, Zhu, D, Niu, X, Wang, D, et al. (2015). Improved hematopoietic differentiation efficiency of gene-corrected beta-thalassemia induced pluripotent stem cells by CRISPR/Cas9 system. Stem cells and development 24: 1053-1065.

190. Martins, GLS, Paredes, BD, Azevedo, CM, Sampaio, GLA, Nonaka, CKV, Cavalcante, BRR, et al. (2018). Generation of integration-free iPS cell lines from three sickle cell disease patients from the state of Bahia, Brazil. Stem cell research 33: 10-14.

191. Haapaniemi, E, Botla, S, Persson, J, Schmierer, B, and Taipale, J (2018). CRISPR-Cas9 genome editing induces a p53-mediated DNA damage response. Nature medicine 24: 927-930.

192. Doulatov, S, Vo, LT, Chou, SS, Kim, PG, Arora, N, $\mathrm{Li}, \mathrm{H}$, et al. (2013). Induction of multipotential hematopoietic progenitors from human pluripotent stem cells via respecification of lineage-restricted precursors. Cell stem cell 13: 459-470.

193. Sugimura, $R$, Jha, DK, Han, $A$, Soria-Valles, $C$, da Rocha, EL, Lu, YF, et al. (2017). Haematopoietic stem and progenitor cells from human pluripotent stem cells. Nature 545: 432-438.

194. Ranjha, L, Howard, SM, and Cejka, P (2018). Main steps in DNA double-strand break repair: an introduction to homologous recombination and related processes. Chromosoma 127: 187214.

195. Adikusuma, F, Piltz, S, Corbett, MA, Turvey, M, McColl, SR, Helbig, KJ, et al. (2018). Large deletions induced by Cas9 cleavage. Nature 560: E8-E9.

196. Cullot, G, Boutin, J, Toutain, J, Prat, F, Pennamen, P, Rooryck, C, et al. (2019). CRISPR- 
Cas9 genome editing induces megabase-scale chromosomal truncations. Nature communications 10: 1136.

197. Broeders, M, Herrero-Hernandez, P, Ernst, MPT, van der Ploeg, AT, and Pijnappel, W (2020). Sharpening the Molecular Scissors: Advances in Gene-Editing Technology. iScience 23: 100789.

198. Hess, GT, Tycko, J, Yao, D, and Bassik, MC (2017). Methods and Applications of CRISPRMediated Base Editing in Eukaryotic Genomes. Molecular cell 68: 26-43.

199. Molla, KA, and Yang, Y (2019). CRISPR/CasMediated Base Editing: Technical Considerations and Practical Applications. Trends in biotechnology 37: 1121-1142.

200. Gaudelli, NM, Komor, AC, Rees, HA, Packer, MS, Badran, AH, Bryson, DI, et al. (2017). Programmable base editing of $A^{*} T$ to $G^{*} C$ in genomic DNA without DNA cleavage. Nature 551: 464-471.

201. Kim, YB, Komor, AC, Levy, JM, Packer, MS, Zhao, $\mathrm{KT}$, and Liu, DR (2017). Increasing the genometargeting scope and precision of base editing with engineered Cas9-cytidine deaminase fusions. Nature biotechnology 35: 371-376.

202. Komor, AC, Kim, YB, Packer, MS, Zuris, JA, and Liu, DR (2016). Programmable editing of a target base in genomic DNA without double-stranded DNA cleavage. Nature 533: 420-424.

203. Nishida, K, Arazoe, T, Yachie, N, Banno, S, Kakimoto, M, Tabata, M, et al. (2016). Targeted nucleotide editing using hybrid prokaryotic and vertebrate adaptive immune systems. Science 353.

204. Kim, K, Ryu, SM, Kim, ST, Baek, G, Kim, D, Lim, K, et al. (2017). Highly efficient RNA-guided base editing in mouse embryos. Nature biotechnology 35: 435-437.

205. Kim, D, Kim, DE, Lee, G, Cho, SI, and Kim, JS (2019). Genome-wide target specificity of CRISPR RNA-guided adenine base editors. Nature biotechnology 37: 430-435.

206. Zuo, E, Sun, Y, Wei, W, Yuan, T, Ying, W, Sun, H, et al. (2019). Cytosine base editor generates substantial off-target single-nucleotide variants in mouse embryos. Science 364: 289-292.

207. Jin, S, Zong, Y, Gao, Q, Zhu, Z, Wang, Y, Qin, P, et al. (2019). Cytosine, but not adenine, base editors induce genome-wide off-target mutations in rice. Science 364: 292-295.

208. Grunewald, J, Zhou, R, Garcia, SP, Iyer, S, Lareau, CA, Aryee, MJ, et al. (2019). Transcriptome-wide off-target RNA editing induced by CRISPRguided DNA base editors. Nature 569: 433-437.

209. Zhou, C, Sun, Y, Yan, R, Liu, Y, Zuo, E, Gu, C, et al. (2019). Off-target RNA mutation induced by DNA base editing and its elimination by mutagenesis. Nature 571: 275-278.

210. Rees, HA, Wilson, C, Doman, JL, and Liu, DR (2019). Analysis and minimization of cellular RNA editing by DNA adenine base editors. Science advances 5: eaax5717.

211. Gehrke, JM, Cervantes, $\mathrm{O}$, Clement, $\mathrm{MK}, \mathrm{Wu}, \mathrm{Y}$, Zeng, J, Bauer, DE, et al. (2018). An APOBEC3ACas9 base editor with minimized bystander and off-target activities. Nature biotechnology 36: 977-982.

212. Liang, $P$, Ding, C, Sun, $H, X i e, X, X u, Y$, Zhang, $X$, et al. (2017). Correction of beta-thalassemia mutant by base editor in human embryos. Protein \& cell 8: 811-822.

213. Zeng, J, Wu, Y, Ren, C, Bonanno, J, Shen, $A H$, Shea, D, et al. (2020). Therapeutic base editing of human hematopoietic stem cells. Nat Med 26: 535-541.

214. Anzalone, AV, Randolph, PB, Davis, JR, Sousa, AA, Koblan, LW, Levy, JM, et al. (2019). Searchand-replace genome editing without doublestrand breaks or donor DNA. Nature 576: 149157.

215. Worsham, DN, Schuesler, T, von Kalle, C, and Pan, D (2006). In vivo gene transfer into adult stem cells in unconditioned mice by in situ delivery of a lentiviral vector. Molecular therapy : the journal of the American Society of Gene Therapy 14: 514-524.

216. Wang, X, Shin, SC, Chiang, AF, Khan, I, Pan, D, Rawlings, DJ, et al. (2015). Intraosseous delivery of lentiviral vectors targeting factor VIII expression in platelets corrects murine hemophilia A. Molecular therapy : the journal of the American Society of Gene Therapy 23: 617626.

217. Habi, O, Girard, J, Bourdages, V, Delisle, MC, and Carreau, M (2010). Correction of Fanconi Anemia Group C Hematopoietic Stem Cells Following Intrafemoral Gene Transfer. Anemia 2010.

218. Andreani, M, Manna, M, Lucarelli, G, Tonucci, $P$, Agostinelli, F, Ripalti, M, et al. (1996). Persistence of mixed chimerism in patients transplanted for the treatment of thalassemia. Blood 87: 3494-3499. 
219. Persons, DA, Allay, ER, Sabatino, DE, Kelly, $P$, Bodine, DM, and Nienhuis, AW (2001). Functional requirements for phenotypic correction of murine beta-thalassemia: implications for human gene therapy. Blood 97: 3275-3282.

220. Finkelshtein, D, Werman, A, Novick, D, Barak, S, and Rubinstein, $M$ (2013). LDL receptor and its family members serve as the cellular receptors for vesicular stomatitis virus. Proceedings of the National Academy of Sciences of the United States of America 110: 7306-7311.

221. DePolo, NJ, Reed, JD, Sheridan, PL, Townsend, K, Sauter, SL, Jolly, DJ, et al. (2000). VSV-G pseudotyped lentiviral vector particles produced in human cells are inactivated by human serum. Molecular therapy : the journal of the American Society of Gene Therapy 2: 218222.

222. Frecha, C, Costa, C, Negre, D, Amirache, F, Trono, D, Rio, P, et al. (2012). A novel lentiviral vector targets gene transfer into human hematopoietic stem cells in marrow from patients with bone marrow failure syndrome and in vivo in humanized mice. Blood 119: 11391150.

223. Milani, M, Annoni, A, Bartolaccini, S, Biffi, M, Russo, F, Di Tomaso, T, et al. (2017). Genome editing for scalable production of alloantigenfree lentiviral vectors for in vivo gene therapy. EMBO molecular medicine 9: 1558-1573.

224. Nilsson, M, Karlsson, S, and Fan, X (2004). Functionally distinct subpopulations of cord blood CD34+ cells are transduced by adenoviral vectors with serotype 5 or 35 tropism. Molecular therapy : the journal of the American Society of Gene Therapy 9: 377-388.

225. Wang, H, Liu, Y, Li, Z, Tuve, S, Stone, D, Kalyushniy, O, et al. (2008). In vitro and in vivo properties of adenovirus vectors with increased affinity to CD46. Journal of virology 82: 1056710579.

226. Richter, M, Saydaminova, K, Yumul, R, Krishnan, R, Liu, J, Nagy, EE, et al. (2016). In vivo transduction of primitive mobilized hematopoietic stem cells after intravenous injection of integrating adenovirus vectors. Blood 128: 2206-2217.

227. Wang, H, Richter, M, Psatha, N, Li, C, Kim, J, Liu, $\mathrm{J}$, et al. (2018). A Combined In Vivo HSC Transduction/Selection Approach Results in Efficient and Stable Gene Expression in
Peripheral Blood Cells in Mice. Molecular therapy Methods \& clinical development 8: 5264.

228. Wang, H, Georgakopoulou, A, Psatha, N, Li, C, Capsali, C, Samal, HB, et al. (2019). In vivo hematopoietic stem cell gene therapy ameliorates murine thalassemia intermedia. The Journal of clinical investigation 129: 598615.

229. Beard, BC, Trobridge, GD, Ironside, C, McCune, JS, Adair, JE, and Kiem, HP (2010). Efficient and stable MGMT-mediated selection of long-term repopulating stem cells in nonhuman primates. The Journal of clinical investigation 120: 23452354.

230. Li, C, Mishra, AS, Gil, S, Wang, $M$, Georgakopoulou, A, Papayannopoulou, T, et al. (2019). Targeted Integration and High-Level Transgene Expression in AAVS1 Transgenic Mice after In Vivo HSC Transduction with HDAd5/35++ Vectors. Molecular therapy : the journal of the American Society of Gene Therapy 27: 2195-2212.

231. Kosicki, M, Tomberg, K, and Bradley, A (2018). Repair of double-strand breaks induced by CRISPR-Cas9 leads to large deletions and complex rearrangements. Nature biotechnology 36: 765-771.

232. Li, C, Psatha, N, Sova, P, Gil, S, Wang, H, Kim, J, et al. (2018). Reactivation of gamma-globin in adult beta-YAC mice after ex vivo and in vivo hematopoietic stem cell genome editing. Blood 131: 2915-2928.

233. Genovese, P, Schiroli, G, Escobar, G, Tomaso, TD, Firrito, C, Calabria, A, et al. (2014). Targeted genome editing in human repopulating haematopoietic stem cells. Nature 510: 235240.

234. Saydaminova, $\mathrm{K}, \mathrm{Ye}, \mathrm{X}$, Wang, $\mathrm{H}$, Richter, $\mathrm{M}, \mathrm{Ho}$, $M$, Chen, $H$, et al. (2015). Efficient genome editing in hematopoietic stem cells with helperdependent Ad5/35 vectors expressing sitespecific endonucleases under microRNA regulation. Molecular therapy Methods \& clinical development 1: 14057.

235. Dever, DP, Bak, RO, Reinisch, A, Camarena, J, Washington, G, Nicolas, CE, et al. (2016). CRISPR/Cas9 beta-globin gene targeting in human haematopoietic stem cells. Nature 539: 384-389.

236. Li, C, Psatha, N, Gil, S, Wang, $H$, Papayannopoulou, T, and Lieber, A (2018). 
HDAd5/35(++) Adenovirus Vector Expressing Anti-CRISPR Peptides Decreases CRISPR/Cas9 Toxicity in Human Hematopoietic Stem Cells. Molecular therapy Methods \& clinical development 9: 390-401.

237. Bahal, R, Ali McNeer, N, Quijano, E, Liu, Y, Sulkowski, P, Turchick, A, et al. (2016). In vivo correction of anaemia in beta-thalassemic mice by gammaPNA-mediated gene editing with nanoparticle delivery. Nature communications 7: 13304

238. Makadia, HK, and Siegel, SJ (2011). Poly Lacticco-Glycolic Acid (PLGA) as Biodegradable Controlled Drug Delivery Carrier. Polymers 3: 1377-1397.

239. Ricciardi, AS, Bahal, R, Farrelly, JS, Quijano, E, Bianchi, AH, Luks, VL, et al. (2018). In utero nanoparticle delivery for site-specific genome editing. Nature communications 9: 2481.

240. Lamsfus-Calle, A, Daniel-Moreno, A, UrenaBailen, G, Raju, J, Antony, JS, Handgretinger, R, et al. (2020). Hematopoietic stem cell gene therapy: The optimal use of lentivirus and gene editing approaches. Blood reviews 40: 100641.

241. Imren, S, Fabry, ME, Westerman, KA, Pawliuk, R, Tang, P, Rosten, PM, et al. (2004). High-level beta-globin expression and preferred intragenic integration after lentiviral transduction of human cord blood stem cells. The Journal of clinical investigation 114: 953-962. 